 \\ Michigan Technological University Create the Future Digital Commons @ Michigan Tech
}

2010

Simulating dioxane transport in a heterogeneous glacial aquifer system (Washtenaw County, Michigan) using publicly available models and data

Rungroj Benjakul

Michigan Technological University

Follow this and additional works at: https://digitalcommons.mtu.edu/etds

Part of the Geology Commons

Copyright 2010 Rungroj Benjakul

Recommended Citation

Benjakul, Rungroj, "Simulating dioxane transport in a heterogeneous glacial aquifer system (Washtenaw County, Michigan) using publicly available models and data", Master's Thesis, Michigan Technological University, 2010.

https://doi.org/10.37099/mtu.dc.etds/313

Follow this and additional works at: https://digitalcommons.mtu.edu/etds

Part of the Geology Commons 


\title{
SIMULATING DIOXANE TRANSPORT IN A HETEROGENEOUS GLACIAL AQUIFER SYSTEM (WASHTENAW COUNTY, MICHIGAN) USING PUBLICLY AVAILABLE MODELS AND DATA
}

\author{
By \\ Rungroj Benjakul
}

\begin{abstract}
A THESIS
Submitted in partial fulfillment of the requirements for the degree of MASTER OF SCIENCE IN GEOLOGY
\end{abstract}

MICHIGAN TECHNOLOGICAL UNIVERSITY

2010

(C) 2010 Rungroj Benjakul 
This thesis, "Simulating Dioxane Transport in a Heterogeneous Glacial Aquifer System (Washtenaw County, Michigan) Using Publicly Available Models and Data," is hereby approved in partial fulfillment of the requirements for the Degree of MASTER OF SCIENCE IN GEOLOGY.

DEPARTMENT:

Geological and Mining Engineering and Sciences

Signatures:

Thesis Advisor

John S. Gierke

Department Chair

Wayne D. Pennington

Date 


\begin{abstract}
The primary challenge in groundwater and contaminant transport modeling is obtaining the data needed for constructing, calibrating and testing the models. Large amounts of data are necessary for describing the hydrostratigraphy in areas with complex geology. Increasingly states are making spatial data available that can be used for input to groundwater flow models. The appropriateness of this data for large-scale flow systems has not been tested. This study focuses on modeling a plume of 1,4-dioxane in a heterogeneous aquifer system in Scio Township, Washtenaw County, Michigan. The analysis consisted of: (1) characterization of hydrogeology of the area and construction of a conceptual model based on publicly available spatial data, (2) development and calibration of a regional flow model for the site, (3) conversion of the regional model to a more highly resolved local model, (4) simulation of the dioxane plume, and (5) evaluation of the model's ability to simulate field data and estimation of the possible dioxane sources and subsequent migration until maximum concentrations are at or below the Michigan Department of Environmental Quality's residential cleanup standard for groundwater (85 ppb). MODFLOW-2000 and MT3D programs were utilized to simulate the groundwater flow and the development and movement of the 1,4-dioxane plume, respectively. MODFLOW simulates transient groundwater flow in a quasi-3-dimensional sense, subject to a variety of boundary conditions that can simulate recharge, pumping, and surface-/groundwater interactions. MT3D simulates solute advection with groundwater flow (using the flow solution from MODFLOW), dispersion, source/sink mixing, and chemical reaction of contaminants. This modeling approach was successful at simulating the groundwater flows by calibrating recharge and hydraulic conductivities. The plume transport was adequately simulated using literature dispersivity and sorption coefficients, although the plume geometries were not well constrained.
\end{abstract}




\section{ACKNOWLEDGEMENT}

I am highly grateful to my advisor, Professor John S. Gierke, for his kind guidance, encouragement, and support for this research. Many thanks are due to Dr. Remigio H. Galárraga-Sánchez and Dr. Aleksey Smirnov for serving as my thesis committee. Special thank to Tyler Fincher for helping me in dealing with English difficulty and review my thesis writing. I would also like to acknowledge my gratitude to the Royal Thai Government for providing me a great opportunity to study in the United States with full financial support. I am grateful to the Department of Geological and Mining Engineering and Sciences and Michigan Technological University for having me here.

I would also like to extend special thanks to Kelly Mclean and Amie Ledgerwood for all their office and registration help, Miriam Rioz Sanchez and Rudiger Escobar Wolf for helping with the GIS data processing, my fellow students: Elisa Piispa, Claudia Toro, Anna Colvin, Edrick Ramos, Anieri Morales, Carla Alonso and many others for all supports and friendship. My willingness to put forward everyday was supported by encouraging words from family and friends. Lastly, I offer my regards and blessings to all of those who supported me in any respect during the completion of the thesis. 


\section{TABLE OF CONTENTS}

ABSTRACT .......................................................................................................................... 3



LIST OF TABLES

LIST OF FIGURES ................................................................................................................ 8

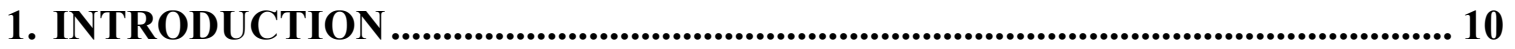

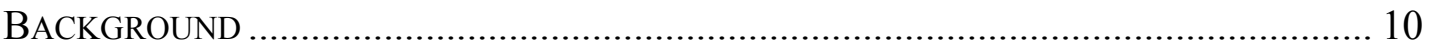

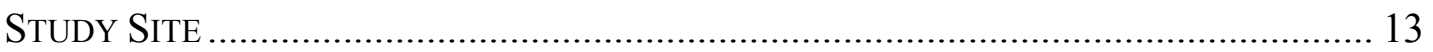

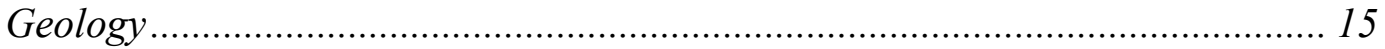

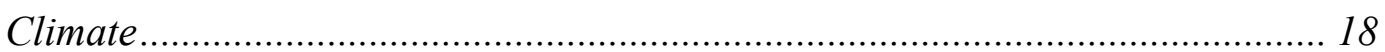

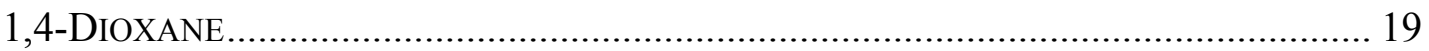

Environmental fate ...................................................................................... 20

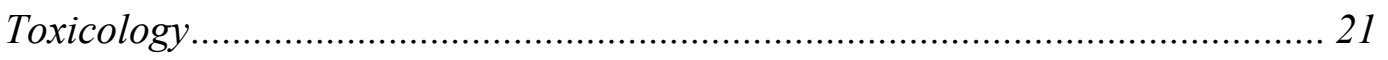

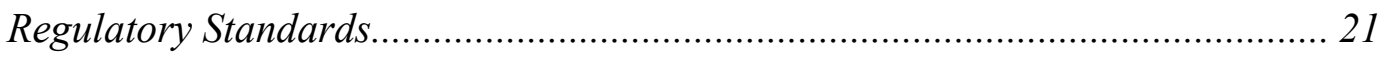

PURPOSE, OBJECTIVES, AND SCOPE ................................................................. 22

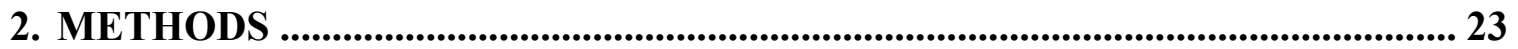

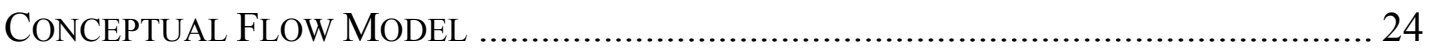

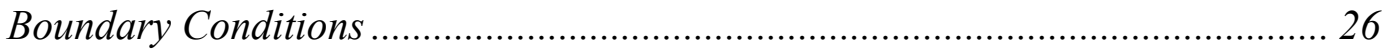





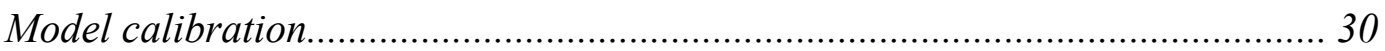



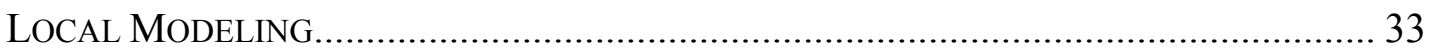

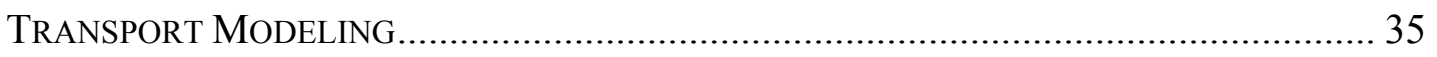

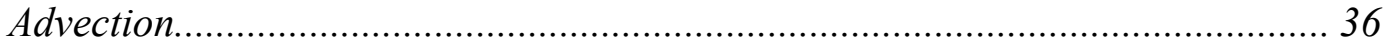

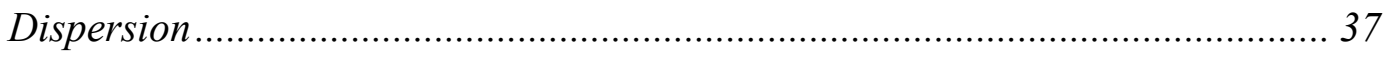

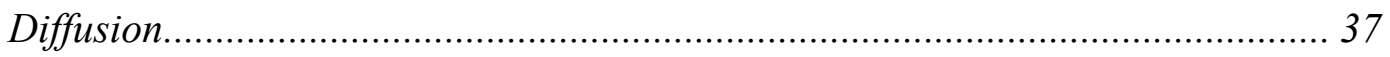

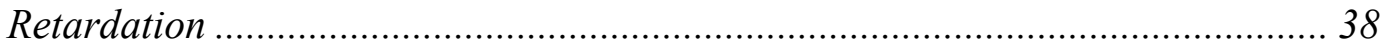




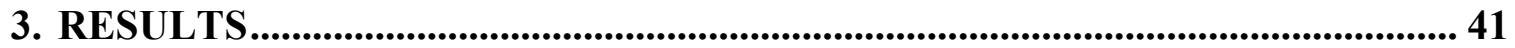



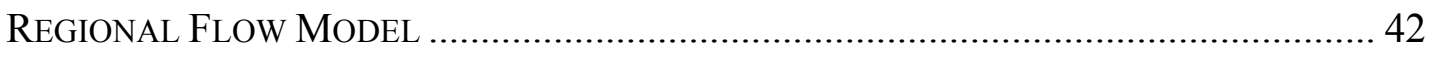

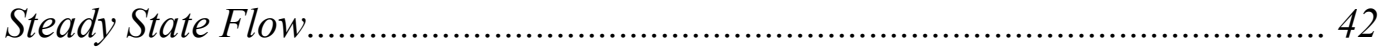

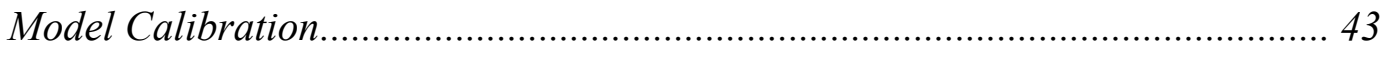

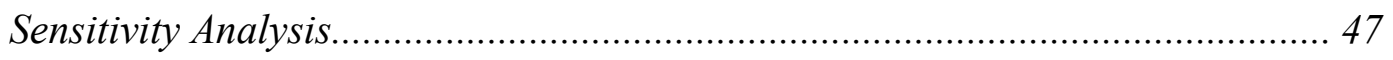

LOCAL FLOW MODEL ……………………………………………………….... 48

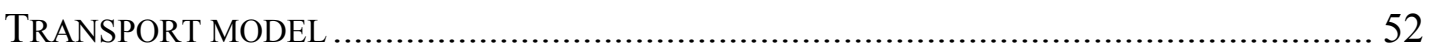

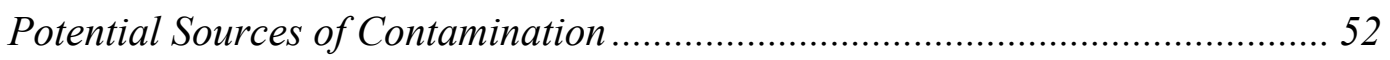

4. DISCUSSION ……............................................................................................................ 55

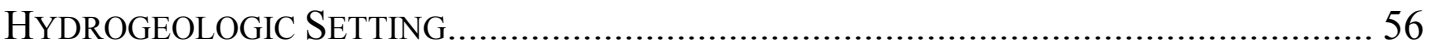

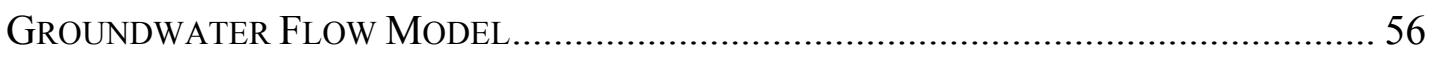

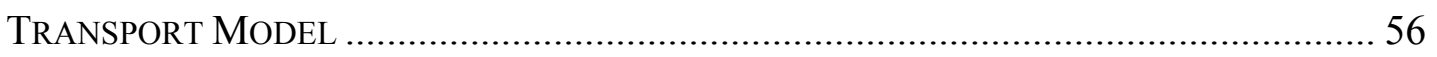



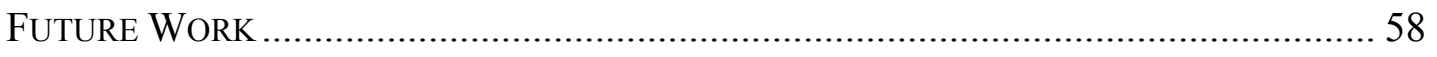

5. CONCLUSIONS................................................................................................................ 61

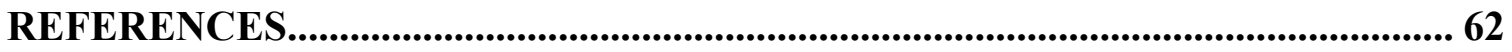






\section{LIST OF TABLES}

Table 1.1 Summary of the geologic Setting of the Western Plume area ............ 17

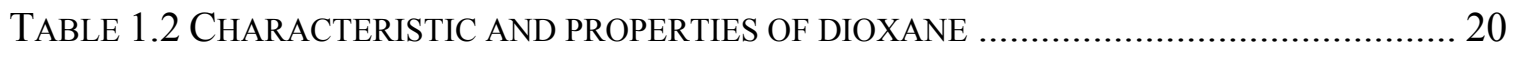

TABLE 2.1 SUMMARY OF THE HYDROGEOLOGY OF THE CONCEPTUAL MODEL.................... 25



TABLE 2.3 GROUNDWATER RECHARGE VALUES ASSIGNED DURING CALIBRATION PROCESS

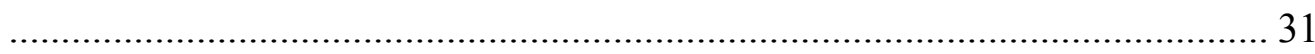

TABLE 3.1 SimULATED WATER BUDGET FOR THE CALIBRATED REGIONAL FLOW MODEL ... 46

TABLE 3.2 SUMMARY OF CALIBRATED PARAMETER VALUES FOR THE REGIONAL MODEL... 47

TABLE 3.3 SUMMARY OF CALIBRATED PARAMETER VALUES AND SENSITIVITIES FOR THE

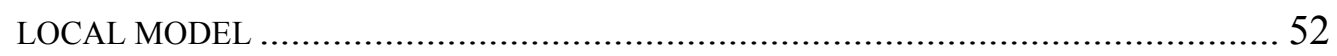

TABLE 4.1 COMPARISON OF THE PUBLISHED MODELS TO THIS STUDY ............................... 55 


\section{LIST OF FIGURES}

FiguRE 1.1 SELECTED IMPORTANT FEATURES IN THE STUDY AREA.................................... 11

FIGURE 1.2 LOCATION MAP OF THE STUDY AREA …………………………………...... 14

FIGURE 1.3 TOPOGRAPHIC MAP OF THE STUDY AREA ………........................................ 14

Figure 1.4 SuRficial Geology of WaShtenaw County ............................................. 17

FiguRE 1.5 ANNUAL PRECIPITATION DATA AT UNIVERSITY OF MiCHIGAN WEATHER



Figure 1.6 ANNUAL temperature DATA AT University of Michigan Weather

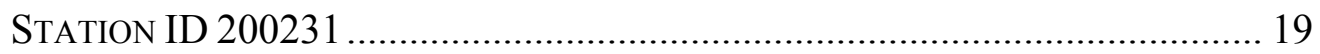

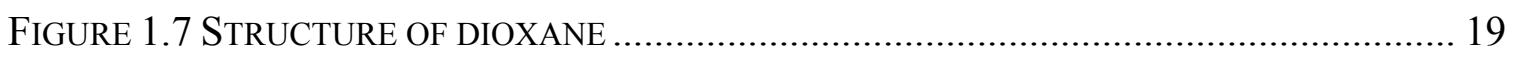

FigURE 2.1 REGIONAL MODEL DOMAIN OF THE CONCEPTUAL MODEL ……………….......... 25

FIGURE 2.2 TOP VIEW OF REGIONAL MODEL EXTENT SHOWING LATERAL GRID SPACING AND



Figure 2.3 GROUNDWATER RECHARGE ZONES, EASTINGS AND NORTHINGS ARE IN FEET . 28

FigURE 2.4 SEPTEMBER 1995 POTENTIOMETRIC SURFACE MAP OF UPPER AQUIFER ........... 31

FIGURE 2.5 LOCAL MODEL EXTENT SHOWING BOUNDARY CONDITIONS ............................. 34

FIGURE 2.6 APRIL, 1988 DELINEATION MAP OF DIOXANE CONCENTRATION IN UPPER

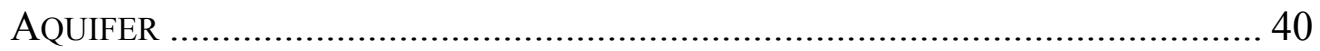

FigURE 3.1 TOP ELEVATION CONTOUR MAP OF THE LOWER CONFINING LAYER ................. 42

FigURE 3.2 STEADY STATE POTENTIOMETRIC SURFACE MAP (REGIONAL MODEL LAYER 2, CONTOURS ARE IN FEET AMSL, EASTINGS AND NORTHINGS ARE IN FEET)........ 43

FigURE 3.3 Plot OF COMPUTED VERSUS OBSERVED HEADS FOR UPPER AQUIFER UNIT IN

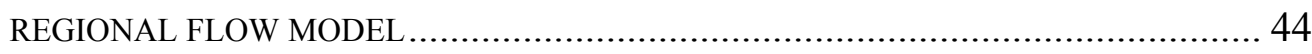

FigURE 3.4 Plot OF RESIDUAL VERSUS OBSERVED HEADS FOR UPPER AQUIFER UNIT IN

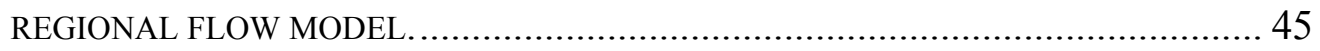

FigURE 3.5 RELATIVE COMPOSITE SENSITIVITY OF CALIBRATED PARAMETERS................... 48

FIGURE 3.6 STEADY STATE POTENTIOMETRIC SURFACE MAP (LOCAL MODEL LAYER 2, CONTOURS ARE IN FEET AMSL, EASTINGS AND NORTHINGS ARE IN FEET)........ 49

FiguRE 3.7 PLOT OF COMPUTED VERSUS OBSERVED HEADS FOR UPPER AQUIFER UNIT IN LOCAL FLOW MODEL. 50 
FIGURE 3.8 PLOT OF RESIDUAL VERSUS OBSERVED HEADS FOR UPPER AQUIFER UNIT IN

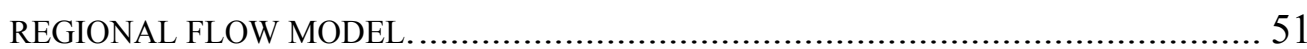

FIGURE 3.9 SiMULATED PLUME DELINEATION MAP IN LOWER AQUIFER WITH INITIAL



FIGURE 3.10 CALIBRATED PLUME DELINEATION MAP IN LOWER AQUIFER ....................... 54 


\section{Introduction}

\section{Background}

Groundwater contamination by 1,4-dioxane (hereinafter called dioxane) has been a concern of government and residents in Washtenaw County, Michigan for almost four decades. Dioxane is harmful to humans' health and found to be stable in water (Agency for Toxic Substances and Disease Registry: ATSDR, 2007). To date, more than a hundred private water wells are contaminated by dioxane released from the Pall Life Sciences (PLS), formerly Gelman Sciences. The Michigan Department of Environmental Quality (MDEQ, 2004) reported that dioxane was used by PLS between 1966 and 1986 to produce medical filters. Disposal method and waste handling during this period resulted in a discharge of dioxane into groundwater. However, the volume of released wastewater and the concentration of the chemical are unknown, which consequently results in uncertainty of the mass-loading history of the area.

Contamination in the wells was first discovered in the fall of 1985 and a comprehensive site investigation started later in 1986 (MDEQ, 2004). The contaminant mapping activities delineated the Core System, the Western System, and the Evergreen System (Figure 1.1). The Core System is the source of contamination, with the concentrations in excess of $500 \mathrm{ppb}(\mu \mathrm{g} / \mathrm{L})$, spans all of the PLS property, wastewater seepage ponds, and surrounding area.

This study focuses on the dioxane plume (also known as the Western Plume) located to the west of a larger area impacted by groundwater contamination in Scio Township, Washtenaw County, Michigan. According to the Consent Judgment, the Western System (or the Western Plume area) is the area of groundwater contamination west, northwest or southwest of the Core System. Thus, the Western Plume area (Figure 1.1) refers to the western area of the PLS site, extending to the confluence of the Honey Creek Tributaries and reaching from a northern extent along Interstate Highway I-94 one mile to the south. The Western System was initially believed to be emanating from the Core System contamination. After the additional site investigation, the perception of this 
area was changed. The Western Plume then has been interpreted separately from the Core System (MDEQ, 2004).

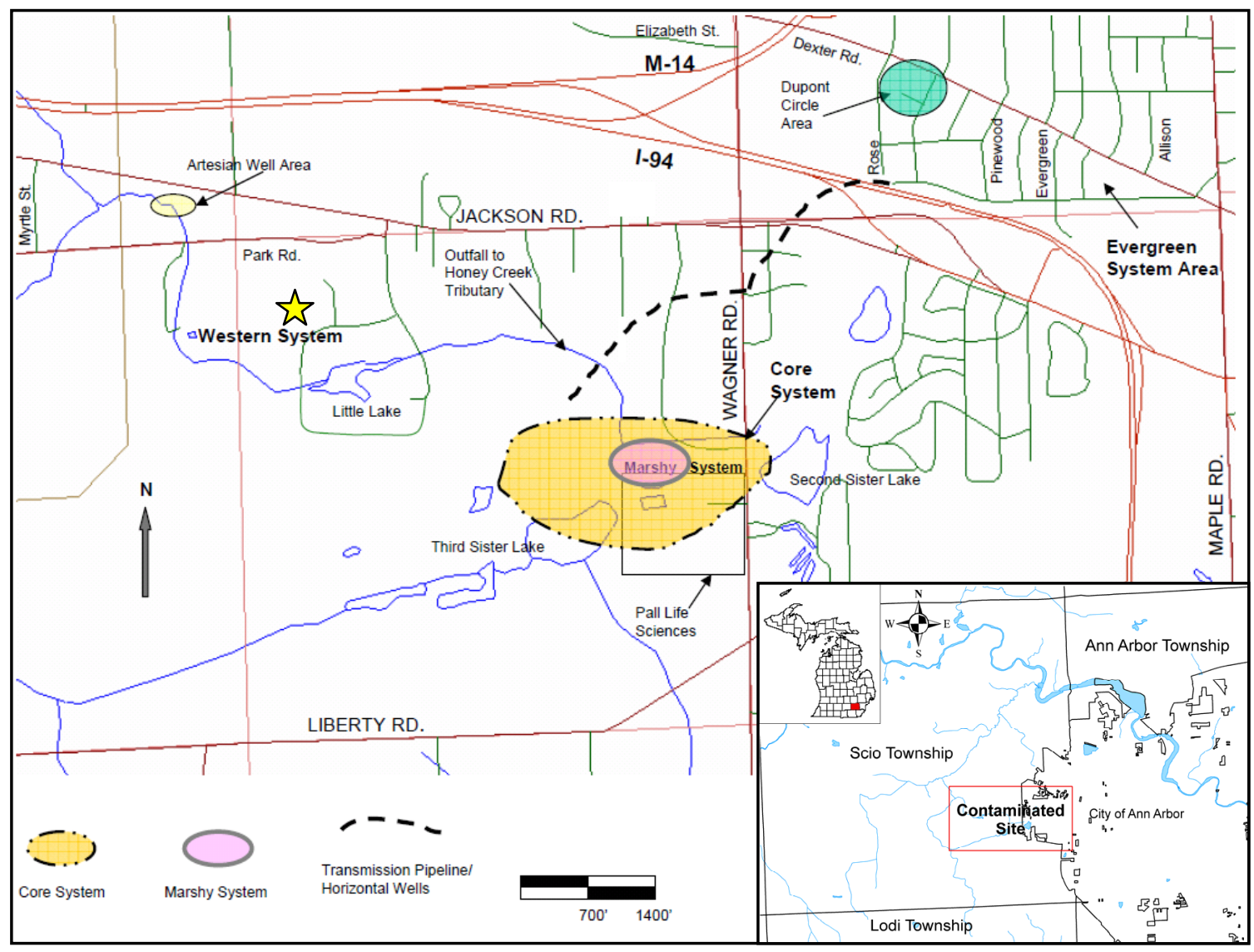

Figure 1.1 Selected important features in the study area (created from MDEQ 2004 and digital data of Michigan Geographic Framework, Michigan Center for Geographic Information). The areas impacted by dioxane contamination include the Core System, the Marshy System, the Western System, the Evergreen System Area, Artesian Well Area and the Dupont Circle Area. The yellow star represents the center of the Western System.

Geologic complexity and limitation in subsurface data are always challenges in analyzing the behavior of a groundwater system. Groundwater modeling is generally considered a valuable approach for describing and/or predicting groundwater flow and contaminant fate and transport. It has been used at many hazardous waste sites with varying degrees of success. Therefore groundwater models were developed for the Western Plume area to better understand the subsurface behavior. The three dimensional (3D) groundwater model developed by Brode (2002) was built to examine the role of 
groundwater and surface water interactions with the development of the groundwater contamination in the study area. It consisted of four model layers representing two aquifers bounded by two confining layers. The model was calibrated with data from eight observation wells in the Western Plume area. An advective transport of dissolved dioxane from Little Lake was simulated using MODPATH (Pollack, 1944), a particle-tracking (advection only) post-processing model, to determine the travel pathways and transport history.

Later, Cypher and Lemke (2009) constructed three alternative conceptual models coupled with the possible locations where the contaminant enters the groundwater to enhance the perception of the aquifer system and reduce the model uncertainty. The analysis was composed of four major procedures: (1) construction of the alternative models for a site, (2) calibration of the models based on the same dataset, (3) ranking the viability of the models using various criteria, and (4) evaluation model appropriateness. The authors utilized the MODFLOW-2000 and MODPATH programs to simulate groundwater flow in the conceptual models and evaluate the transport pathway, respectively. After running all models under steady state condition, the models were calibrated using the potentiometric surface of the static water level data in September 1995, which is the date before the remediation at the site was implemented. The authors also examined the sensitivity of the models to small changes in model parameters and boundary conditions. As a result, the contaminated Core System area, i.e., the holding ponds and Third Sister Lake, were identified as the most probable sources of the Western Plume. Nevertheless, further refinement of the conceptual and numerical model was suggested for this area based on additional publically available data and more mechanistically sophisticated transport modeling.

Regional modeling studies of groundwater contamination have not been common due to the inherent complexity of computer modeling and the dearth of data for many sites. Lack of field investigation data for studying contaminant behavior is always a challenge for contaminant transport modeling. State laws and local ordinances require that hydrogeological data be collected and reported for domestic water purposes, both for private and community supplies, as well as for construction, industrial and agricultural 
purposes. Prior to the prevalence of geographical information systems (GIS), this data was filed away, often in non-centralized fashion, making data gathering problematic. Currently, however, hydrogeological information for water supply purposes is commonly archived in publically accessible sites, typically maintained by state departments of environmental quality/natural resources. In addition, even information on contaminated sites (contaminant concentrations in soils and groundwater) are available. The goal of this work is to use publically available data to construct regional and local models of groundwater flow and contaminant transport for a field site where modeling was performed previously using fewer data sources. The objective is to demonstrate that the

publically available data can be used with publically available models to adequately simulate field conditions in a complex glacial aquifer system contaminated with 1,4dioxane. The site conditions and important contaminant properties are outlined below.

\section{Study Site}

This study focused on the contamination in a shallow aquifer of the Western Plume System located in Scio Township, Washtenaw County, Michigan as shown in Figure 1.2. The Sister Lakes and the Honey Creek and its tributary are the significant hydrographic features in the area (Figure 1.2). The Western Plume System is one of the areas impacted by dioxane contamination released from the PLS located on Wagner Road (Figure 1.1). The topography of this area ranges from 940 feet above mean sea level (amsl) in the vicinity of the PLS property to the lower area of approximately 850 feet amsl at the Honey Creek (Figure 1.3). Five major aquifers are identified in the area: the Core System, the Western System, the Evergreen System, the Marshy System, and the Unit E aquifer (MDEQ, 2004). These aquifers can be grouped as shallow and deep aquifers. The Unit E aquifer is only a deep aquifer in this area. A significant pumping remediation in the Core System area started in 1997, twelve years after the contamination was first discovered. 


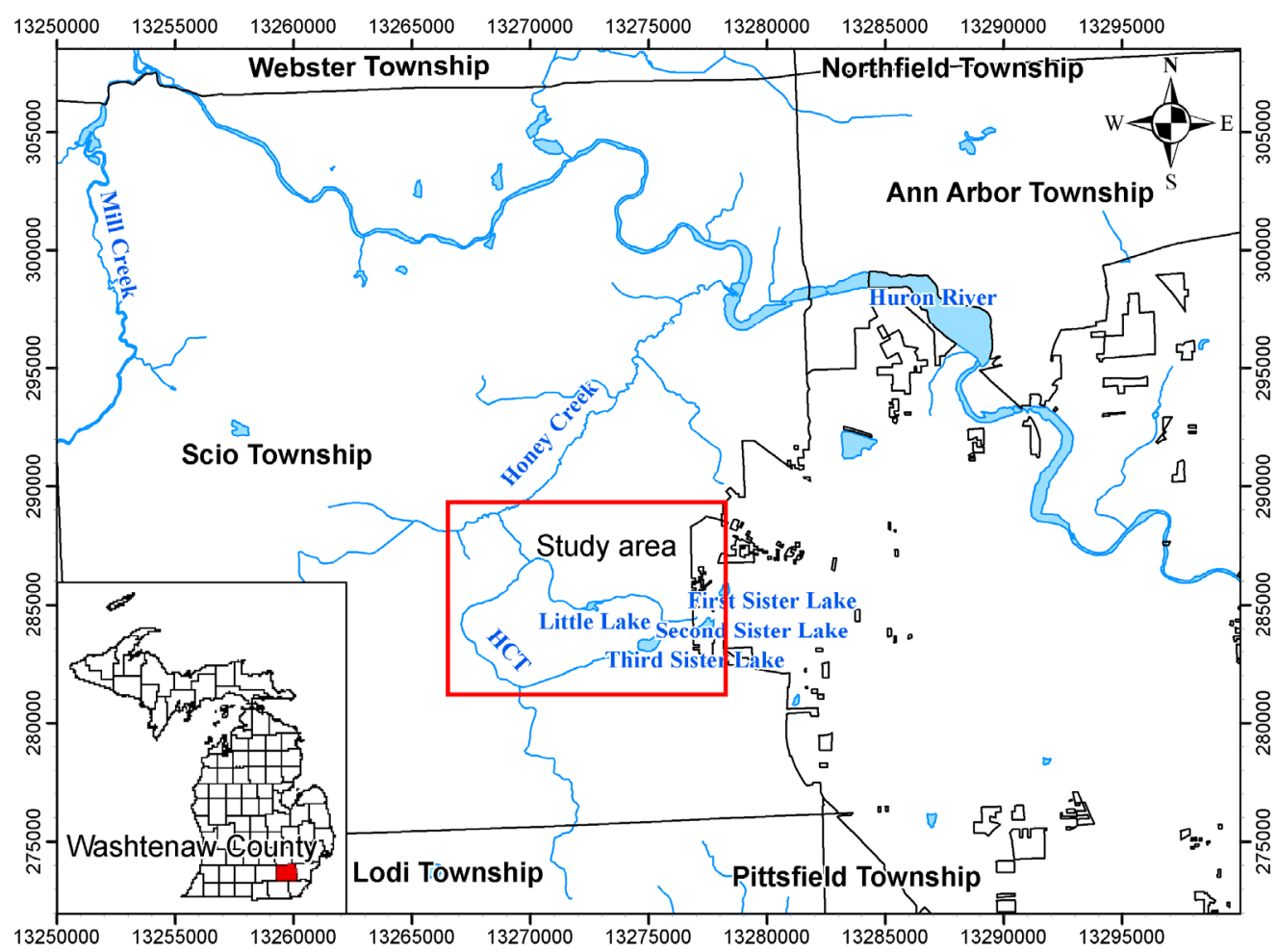

Figure 1.2 Location map of the study area, Eastings and Northings are in feet.

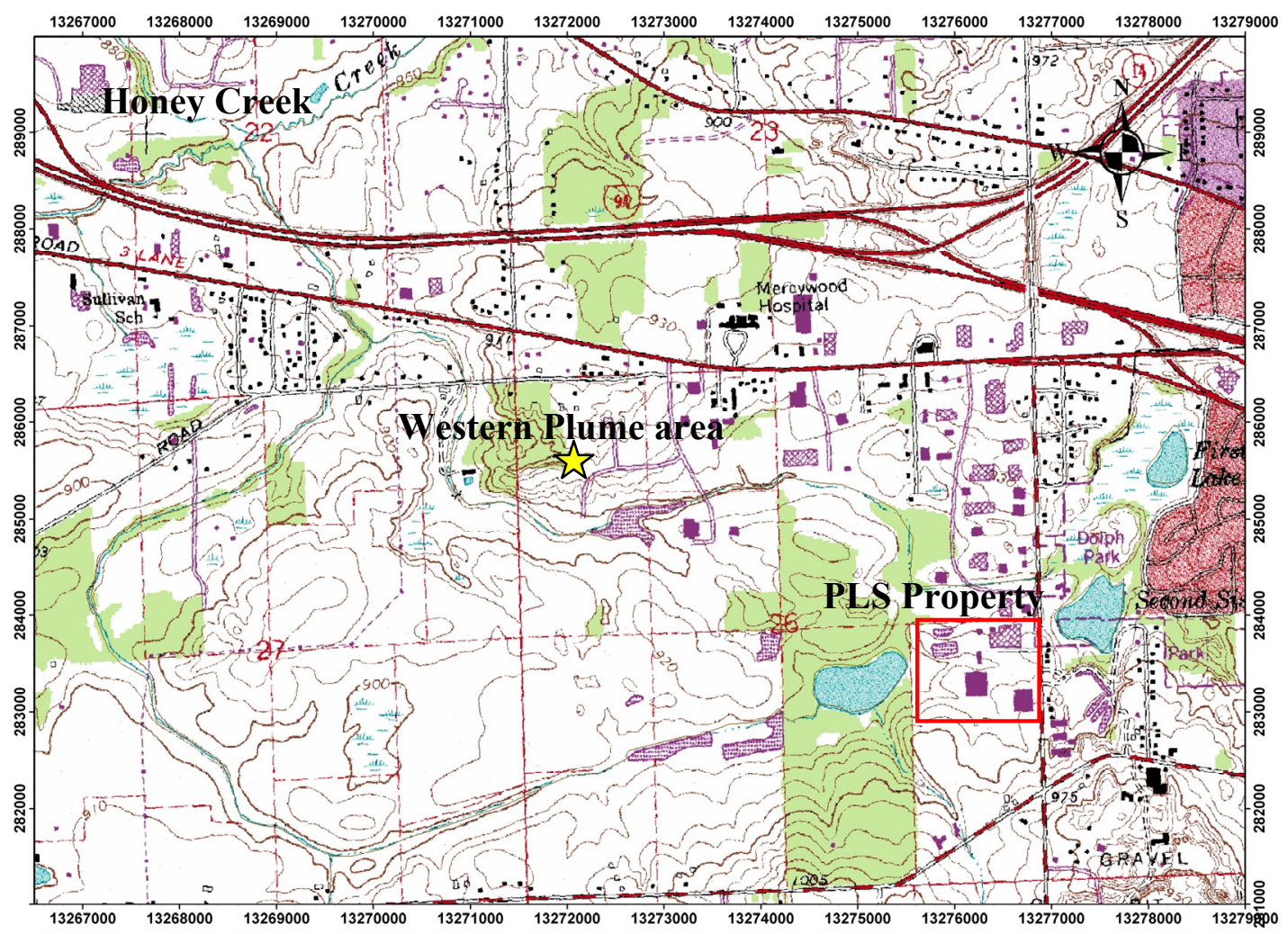

Figure 1.3 Topographic map of the study area, Eastings and Northings are in feet. 
The public data related to the study site can be accessible through the state government website. The current and historical information on the investigation and remediation of groundwater contamination are provided by the Michigan Department of Natural Resources and Environment (MDNRE). Selected documents, letters, and maps are downloadable on the MDNRE website. The Michigan Center for Geographic Information (MCGI) provides several statewide datasets concerning aerial imagery, census, geology, groundwater, hydrography, hydrology, land cover, land use, political features, soils, topography, transportation and much more through the Michigan Geographic Data Library. The library consists of several data format with various spatial and temporal resolutions. The data are categorized and can be sorted based on geographic extent or theme type.

There are two previous studies primarily concerning the contamination in the Western Plume area (Brode, 2002; Cypher and Lemke, 2009). Brode (2002) investigated the effect of an interaction between groundwater and surface water on the development of dioxane plume in the Western Plume area by using a numerical model. The numerical model was based on a four-layered conceptual model. Cypher and Lemke (2009) established alternative conceptual models to describe the hydrogeologic complexity of this area and the four-layered conceptual model was also included in the study. Both studies utilized MODPATH to simulate an advective transport of dioxane from the potential source locations. Brode indicated that the Little Lake served as a source of the Western Plume. In contrast, Cypher and Lemke (2009) concluded that the dioxane was possibly released from the Third Sister Lake and the hydrogeologic complexity played the important role in the groundwater system behavior.

\section{Geology}

The geology of Washtenaw County can be categorized into two major groups: unconsolidated sediments (glacial drift deposits) and bedrock. The bedrock is primarily sedimentary rocks with a thickness of 1.2 to 2.1 kilometers. The glacial deposits overlie the bedrock, primarily the Coldwater Shale, across nearly all the county (Fleck, 1980). The Coldwater Shale is relatively impermeable and has a maximum thickness of more than 300 meters. The glacial deposits are composed of lakebeds, outwash, deltas and 
moraines. Moraines are a combination of clay, silt, sand, and gravel. Outwash is composed of mostly sand and gravel. Moraines and outwash cover the majority of the county. Figure 1.4 illustrates a surficial geology map of Washtenaw County showing the Western Plume area location. Glacial lithology cannot be regionally correlated in the subsurface possibly due to the heterogeneity of glacial deposits. Aquifers in the glacial deposits mostly consist of sands and gravels and vary regionally in thickness and permeability. Twenter et al. (1976) categorized the glacial deposits of Washtenaw County as a combination of aquifer and non-aquifer materials. Aquifer units consist of permeable materials. Non-aquifer units include clay, hardpan, and heterogeneous fine-grained deposits with low permeability.

In the Western Plume area, the top elevation of the Coldwater Shale is approximately 720 feet amsl. Above the bedrock are the glacial deposits, which generally are low to medium permeable clay or till (Fleck, 1980). Till is fine to coarse grained and presents in moraines and till plains. The Western Plume area is located along the northwestern flank of the Fort Wayne Moraine. Its surface geology is characterized by glacial outwash sands and gravels, terminal moraine ablation tills, and compacted ground moraine tills. The thickness of glacial drift in the Western Plume area ranges from approximately 130 to 250 feet (Cypher, 2008). The stratigraphy of the deposits is quite complex. The influences of the cycles of erosion and deposition of the successive glacial episodes resulted in a lack of continuity of these units. However, there are at least 5 distinct deposits associated with the Western Plume area (Brode, 2002) as summarized in Table 1.1. 


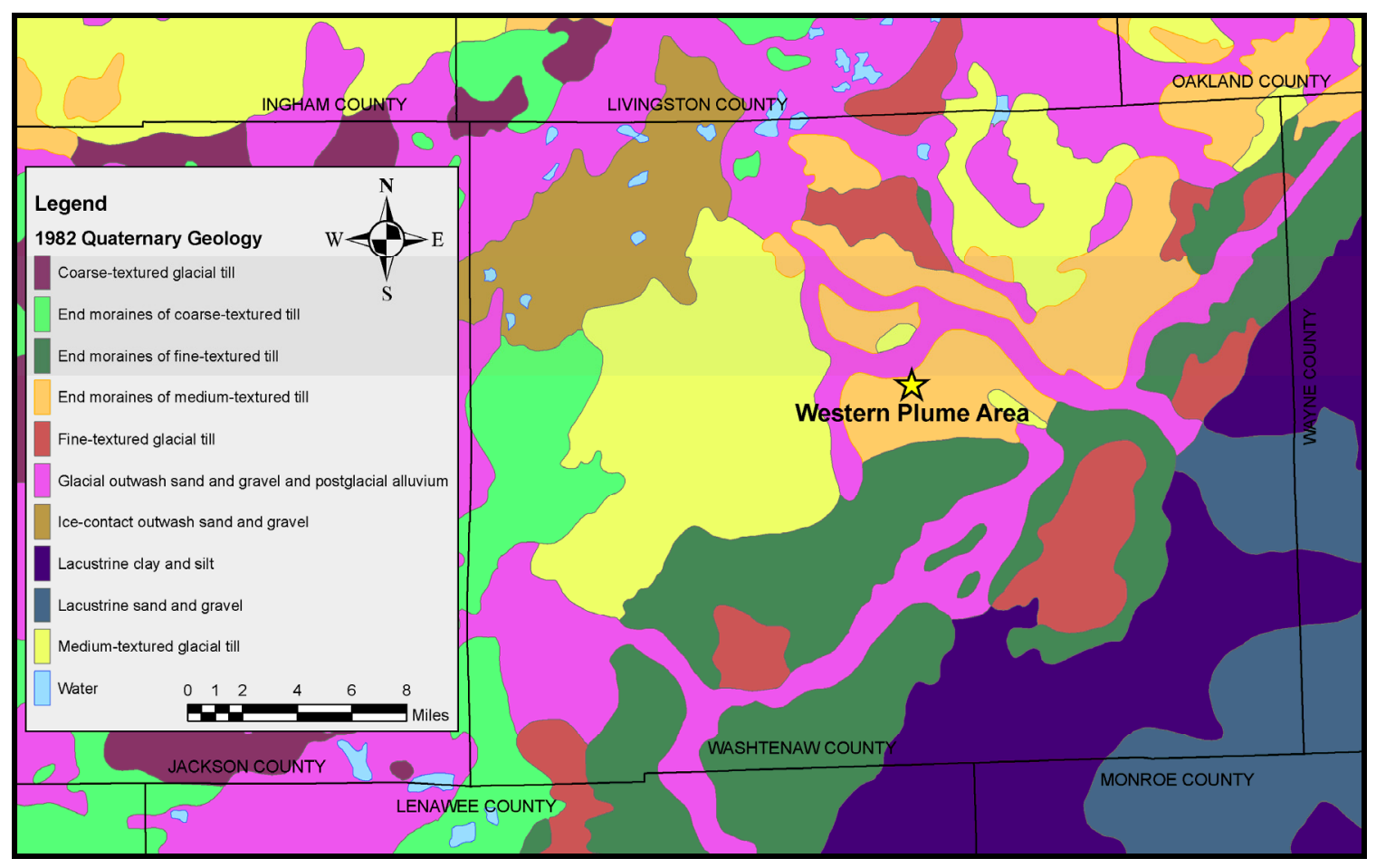

Figure 1.4 Surficial Geology of Washtenaw County (created from digital data of 1982 Quaternary geology maps of northern and southern Michigan, Michigan Center for Geographic Information).

Table 1.1 Summary of the geologic setting of the Western Plume area

\begin{tabular}{|c|c|c|c|c|c|}
\hline & Description & Type & Composition & $\begin{array}{l}\text { Top elevation } \\
\text { (feet amsl) }\end{array}$ & $\begin{array}{c}\text { Thickness } \\
\text { (feet) }\end{array}$ \\
\hline \multirow[t]{4}{*}{ Top } & $\begin{array}{l}\text { Fine-grained } \\
\text { deposit }\end{array}$ & $\begin{array}{l}\text { Confining } \\
\text { layer }\end{array}$ & $\begin{array}{l}\text { Diamictons: reddish- } \\
\text { brown to grey clayey } \\
\text { silts and are commonly } \\
\text { interbeded with sands } \\
\text { and gravels }\end{array}$ & $\begin{array}{l}\text { Highest at } \\
1069\end{array}$ & $\begin{array}{c}\text { Generally } \\
<20\end{array}$ \\
\hline & $\begin{array}{l}\text { Upper sand } \\
\text { and gravel }\end{array}$ & $\begin{array}{l}\text { Aquifer (both } \\
\text { confined and } \\
\text { unconfined) }\end{array}$ & $\begin{array}{l}\text { Primarily coarse sands } \\
\text { and various amounts of } \\
\text { gravel with some finer- } \\
\text { grained sands and silts. }\end{array}$ & $\sim 840-940$ & $\begin{array}{l}\text { Less than } \\
40 \text { to } 160\end{array}$ \\
\hline & $\begin{array}{l}\text { Fine-grained } \\
\text { deposit }\end{array}$ & $\begin{array}{l}\text { Confining } \\
\text { layer }\end{array}$ & $\begin{array}{l}\text { Primarily diamicton: } \\
\text { grey silty clay or clayey } \\
\text { silt having a massive } \\
\text { texture and traces of } \\
\text { sand and gravel }\end{array}$ & $\sim 760-860$ & $\sim 15-120$ \\
\hline & $\begin{array}{l}\text { Lower sand } \\
\text { and gravel }\end{array}$ & Aquifer & $\begin{array}{l}\text { Generally coarse sands } \\
\text { with various amounts of } \\
\text { gravel. }\end{array}$ & $\sim 740-780$ & $\sim 20-50$ \\
\hline Bottom & $\begin{array}{l}\text { Coldwater } \\
\text { Shale } \\
\text { Formation: }\end{array}$ & Bedrock & $\begin{array}{l}\text { grey to bluish-grey } \\
\text { shale with very low } \\
\text { permeability }\end{array}$ & Average $\sim 720$ & $\begin{array}{l}\sim 500- \\
1300\end{array}$ \\
\hline
\end{tabular}




\section{Climate}

The study area is located in the Southeast Lower climate division (Eichenlaub et al., 1990). Climate data for the period 1980 to 2007, the period relevant to this investigation, was obtained from the online climate data directory (NOAA 2009). Annual precipitation data acquired from the University of Michigan Weather Station (Station ID 200230) for the period from 1966 through 2008 is provided in Figure 1.5. The average annual precipitation for this period was approximately 35.5 inches $(902 \mathrm{~mm})$, with the highest precipitation mostly occurring during the month of June and the lowest amount in February. The average annual mean temperature of the area between 1966 and 2008 was approximately $49.5 \mathrm{~F}^{\mathrm{o}}\left(9.7^{\circ} \mathrm{C}\right)$ (Figure 1.6)

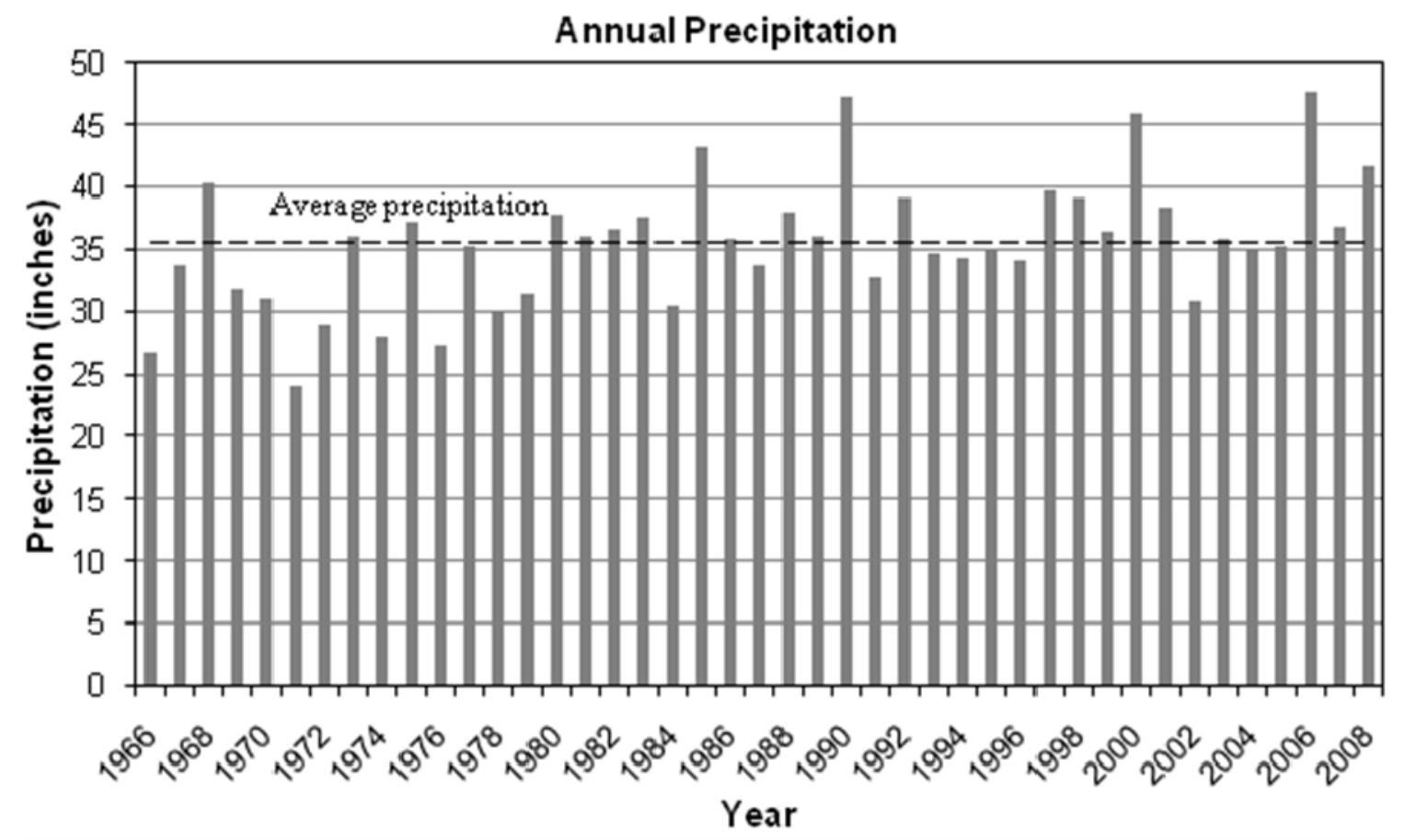

Figure 1.5 Annual precipitation data at University of Michigan Weather Station ID 200231. 


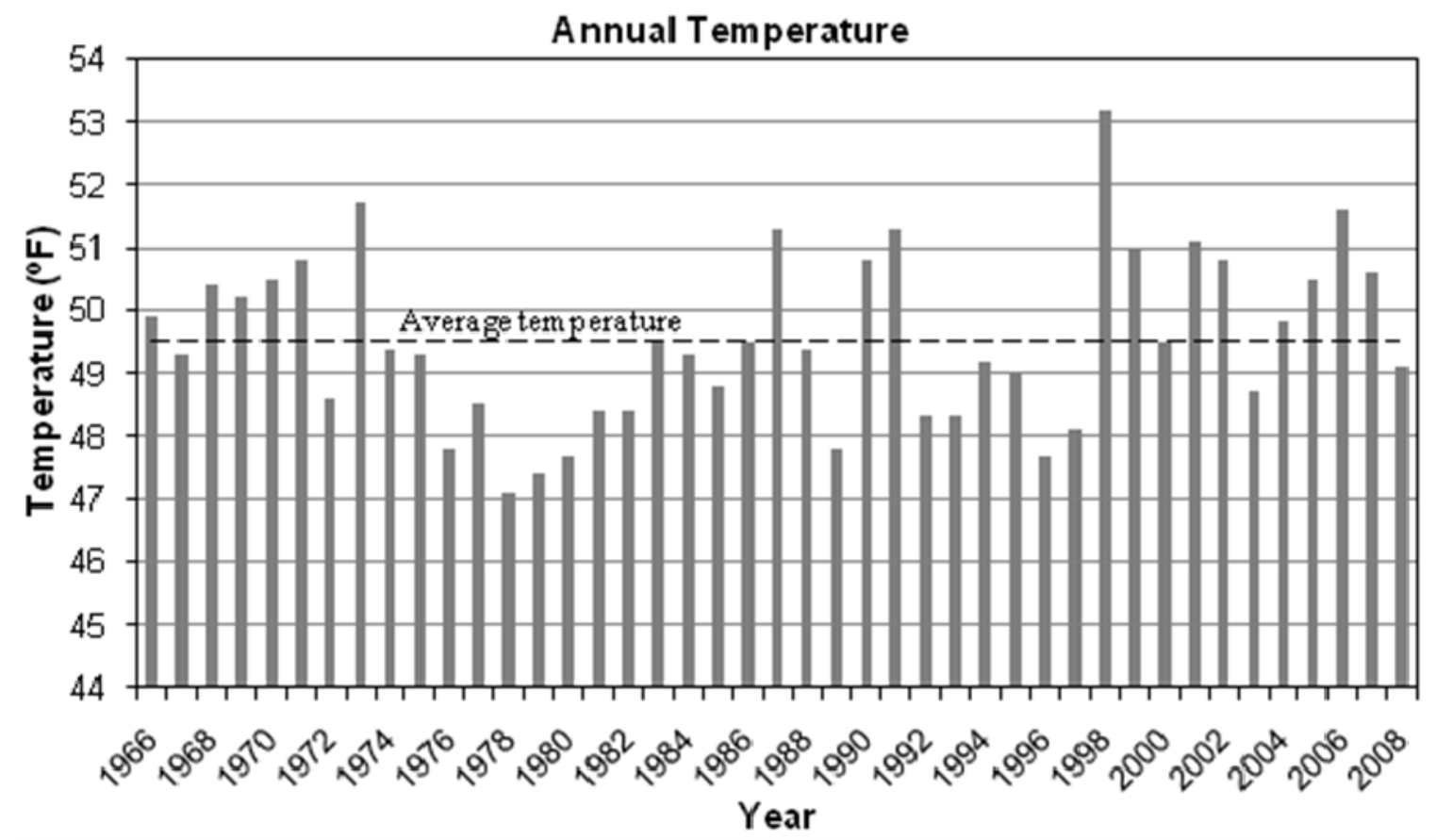

Figure 1.6 Annual temperature data at University of Michigan Weather Station ID 200231.

\section{1,4-Dioxane}

1,4-Dioxane is produced from the dehydration of ethylene glycol and is a strong acid catalyst. It has been used for a wide variety of industrial purposes such as a purification of prescriptions, production of dye, and textile finishing. It is generally used as a solvent stabilizer (USEPA, 2006; Mohr, 2010). Dioxane (also known as diethylene ether, diethylene dioxide, $p$-dioxane, and glycol ethylene ether) is a highly stable synthetic organic compound (Mohr, 2001). It is miscible and highly mobile in groundwater. The molecular formula of dioxane is $\mathrm{C}_{4} \mathrm{H}_{8} \mathrm{O}_{2}$, which has a molecular weight of $88.10 \mathrm{~g} / \mathrm{mole}$. The chemical structure of dioxane is shown in Figure 1.7. The physical and chemical properties and the characteristics of dioxane are listed in Table 1.2.

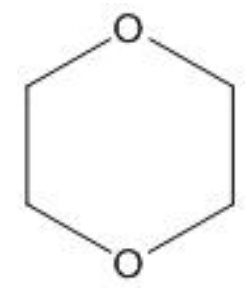

Figure 1.7 Structure of dioxane. 
Table 1.2 Characteristic and properties of dioxane

\begin{tabular}{ll}
\hline Characteristic/Property & Value \\
\hline Chemical Abstracts Service Registry Number (CASRN) & $123-91-1$ \\
EPA Hazardous Waste Identification Number & $\mathrm{U} 108$ \\
Color & Clear \\
Physical State & Flammable liquid, colorless \\
Odor & Faint pleasant odor \\
Molecular Formula & $\mathrm{C}_{4} \mathrm{H}_{8} \mathrm{O}_{2}$ \\
Molecular Weight & 88.1 \\
Molar volume & $85.8 \mathrm{~cm}^{3} / \mathrm{mole}$ at $25^{\circ} \mathrm{C}$ \\
Melting Point & $11.80^{\circ} \mathrm{C}$ at $760 \mathrm{~mm} \mathrm{Hg}$ \\
Boiling Point & $101.1^{\circ} \mathrm{C}$ at $760 \mathrm{~mm} \mathrm{Hg}$ \\
Heat of vaporization & $98.6 \mathrm{cal} / \mathrm{g}$ \\
Water Solubility mg/L at $20^{\circ} \mathrm{C}$ & $\mathrm{Miscible}$ \\
Density & $1.0329 \mathrm{~g} / \mathrm{mL}$ at $20^{\circ} \mathrm{C}$ \\
Vapor Density (air $=1)$ & 3.03 \\
Evaporation rate & 2.42 \\
Viscosity at $20^{\circ} \mathrm{C}$ & $0.012 \mathrm{poise}$ \\
Soil-water partition coefficient, $\mathrm{K}_{\mathrm{OC}}$ & 1.23 \\
Log of octanol-water partition coefficient $\left(\right.$ Log $\left.\mathrm{K}_{\mathrm{OW}}\right)$ & -0.27 \\
Vapor Pressure & $30 \mathrm{~mm} \mathrm{Hg}$ at $20^{\circ} \mathrm{C}$ \\
Flash Point & $5-18^{\circ} \mathrm{C}$ at $760 \mathrm{~mm} \mathrm{Hg}$ \\
Henry's Law Constant, $\mathrm{K}_{\mathrm{H}}$ & $4.88 \times 10^{-6}$ atm m ${ }^{3} / \mathrm{mole}$ \\
Ultraviolet light absorption maximum & $180 \mathrm{~nm}$ \\
\hline Sorce $A S T D$ &
\end{tabular}

Source: ASTDR 2007, EPA 2006, Mohr 2010

Note: atm = atmosphere; $c$ al = calories; $g=$ grams; $L=$ liter; $m L=$ milliliters; $m m H g=$ millimeters of mercury; $m g=$ milligrams; $\mathrm{nm}=$ nanometers; ${ }^{\circ} \mathrm{C}=$ degrees Celsius

\section{Environmental fate}

Since dioxane is a highly soluble compound, it is very mobile and migrates rapidly in groundwater. Its high solubility, low Henry's Law Constant, and low log $\mathrm{K}_{\mathrm{ow}}$ result in a slight retardation (ATSDR, 2007; Mohr, 2010). The study of Priddle and Jackson (1991) suggests that retardation factors $\left(\mathrm{R}_{\mathrm{f}}\right)$ based on field data, correlation estimates, and column data are from 1.0 to 1.6. Biodegradability of dioxane has been studied since the early 1960s (Fincher and Payne, 1962). Many studies have reported that dioxane is not significantly biodegradable (Abe, 1999; USEPA, 2006; Lesage et al., 
1990; Skadsen et al., 2004). Most of these studies were conducted under aerobic biodegradation. Dioxane was not degradable under anaerobic conditions in two studies (Adams et al., 1994; Steffan, 2006). The cyclic-ether structure of dioxane is believed to be a key of its resistance to natural biodegradation (Grady et al., 1997). Nevertheless, Howard (1991) indicated that the half-life of dioxane in groundwater based on estimated non-acclimated aqueous aerobic biodegradation is 56 to 360 days.

\section{Toxicology}

Dioxane enters the human body by inhalation, ingestion, and dermal contact. Short-term exposure may cause eye, nose, and throat irritation. Exposure to large amounts of dioxane can cause kidney and liver damage and eventually death. Liver and kidney toxicity are the health effects resulted from a long-term exposure. Dioxane is categorized in Group B2 (probable human) carcinogen. Two studies have revealed liver cancer in laboratory rats with exposure to the chemical (ATSDR, 2007; Goldsworthy et al., 1991). Although there is no case of carcinogenicity in humans, it is believed that cancer may occur in humans as well. The length and quantity of exposure to dioxane are the factors that control the possible health effects on humans.

\section{Regulatory Standards}

Dioxane concentration criteria for drinking water and groundwater vary state by state, between 3 and $85 \mu \mathrm{g} / \mathrm{L}$. Michigan does not list a Maximum Contaminant Level (MCL) for dioxane. At the time of the contaminant discovery, the standard for groundwater was 3 parts per billion $\left(\mathrm{ppb}^{1}\right)$. The State relaxed the generic residential cleanup criteria to $77 \mathrm{ppb}$ in 1994 (MDEQ, 2004). The current residential cleanup standard for groundwater regulated by Michigan Department of Environmental Quality is $85 \mathrm{ppb}$ and has been used since June 2000 .

\footnotetext{
${ }^{1}$ At dilute concentrations in water, such as those common to groundwater contamination, $1 \mathrm{ppb}$ is practically equal to $1 \mu \mathrm{g} / \mathrm{L}$.
} 


\section{Purpose, Objectives, and Scope}

The primary objective of this study was to simulate the dioxane fate and transport in the Western Plume area. Publicly available spatial data were obtained and analyzed to characterize the hydrogeology of the area and develop the regional conceptual model. The construction of the conceptual model was based on the four-layered models in the prior studies. The simulation of groundwater flow and contaminant transport was accomplished by utilizing a sophisticated computer modeling approach. MODFLOW2000 was selected as the groundwater flow modeling code for this study. A combination of advection, dispersion, and sorption were introduced to the transport model by using MT3D program. In addition, the potential sources and subsequent migration of dioxane plume were assessed. The historical plume movement was estimated until the maximum concentrations diminish to the MDEQ's cleanup standard ( $85 \mathrm{ppb}$ ) or less. 


\section{Methods}

MODFLOW, the most widely-used groundwater flow model developed by the McDonald and Harbaugh (1988) of the U.S. Geological Survey, was utilized in this analysis to simulate the 3-dimensional, regional and local groundwater flows in the aquifer system. In order to more efficiently develop the MODFLOW models, Groundwater Modeling System (GMS) version 6.5 was selected for operating MODFLOW-2000 input and output in this study. The GMS program is a pre and post processor with a graphical user interface, developed by Aquaveo, LLC in Provo, Utah. This program was chosen because it supports a 3D finite difference modeling with the MODFLOW-2000 (saturated zone) and a simple 3D transport with MT3DMS. The program also provides a conceptual modeling approach, a useful tool for constructing a complex 3D stratigraphy and a conceptual model. The MT3DMS is a new version of the Modular $\underline{3}$-Dimensional Transport model (MT3D) developed by Zheng and Wang (Zheng and Wang, 1999). The program provides an additional function to cope with a multi-species transport.

Data utilized in this study was collected from publicly available sources, most of which are accessible on the internet. All Geographic Information System (GIS) data relevant to the site, e.g., topographic map, Digital Elevation Model (DEM), borehole data, Quaternary geology, hydrographic features, estimated groundwater recharge, and legislative political boundaries were obtained from a digital database of the Michigan Geographic Data Library. The historical and current information of the contaminated site such as well information and historical sampling data are available on the Michigan Department of Natural Resources and Environment website. In addition, the National Oceanic and Atmospheric Administration (NOAA) provided the meteorological data, including temperature and precipitation, for the study area.

Once all required data were obtained and properly processed for use in the modeling, identification of spatial model parameters and data analysis were undertaken in order to understand the aquifer system and contaminant transport. To accomplish the goal of this study, the analysis consisted of five primary steps: (1) characterization of 
hydrogeology of the area and construction of a conceptual model based on publicly available spatial data, (2) development and calibration of a regional flow model for the site, (3) conversion of the regional model to a more highly resolved local model, (4) simulation of the dioxane plume, and (5) evaluation of the model's ability to simulate field data and estimation of the possible dioxane sources and subsequent migration until maximum concentrations are at or below the Michigan Department of Environmental Quality's residential cleanup standard for groundwater (85 ppb).

\section{Conceptual Flow Model}

A conceptual flow model is a basic graphical representation of the characteristics of the groundwater flow system that are important in developing the numerical model (Anderson and Woessner, 1992). The conceptual model provides the framework of the state of the flow system, horizontal and vertical boundaries of the model, and interaction with sources and sinks of water. Development of the conceptual model requires a review of literature and data regarding the aquifer system and groundwater flow in the study area.

The regional model domain of the study site covers an area of 65.5 square miles, including all of Scio Township, the northern parts of Lodi and Pittsfield Townships and the western part of Ann Arbor Township (Figure 2.1). The real-world coordinate of the southwest corner of the regional model is (13,250,000 ft East, 272,000 ft North) using the State Plane North American Datum 1983, Michigan South Zone 2113 coordinate system. The coordinate of the northeast corner of the model is $(13,300,000 \mathrm{ft}$ East, 308,500 ft North). This regional model consists of four layers representing the glacial drift deposits in the area, including two confining layers and two aquifers as summarized in Table 2.1. Layer 1, the Upper Confining Layer (UCL), represents deposits above the Upper Aquifer (UA), layer 2. These deposits are primary diamicton (mixed particle-sized sediments), fill, and clays. Layer 2 represents the UA, which is of primary interest to this study. Layer 3 (Lower Confining Layer, LCL) is a confining layer that separates the Upper Aquifer and Lower Aquifer (LA). Layer 4 represents the LA, another aquifer overlying the bedrock surface. Shale bedrock is treated as a no-flow boundary. 


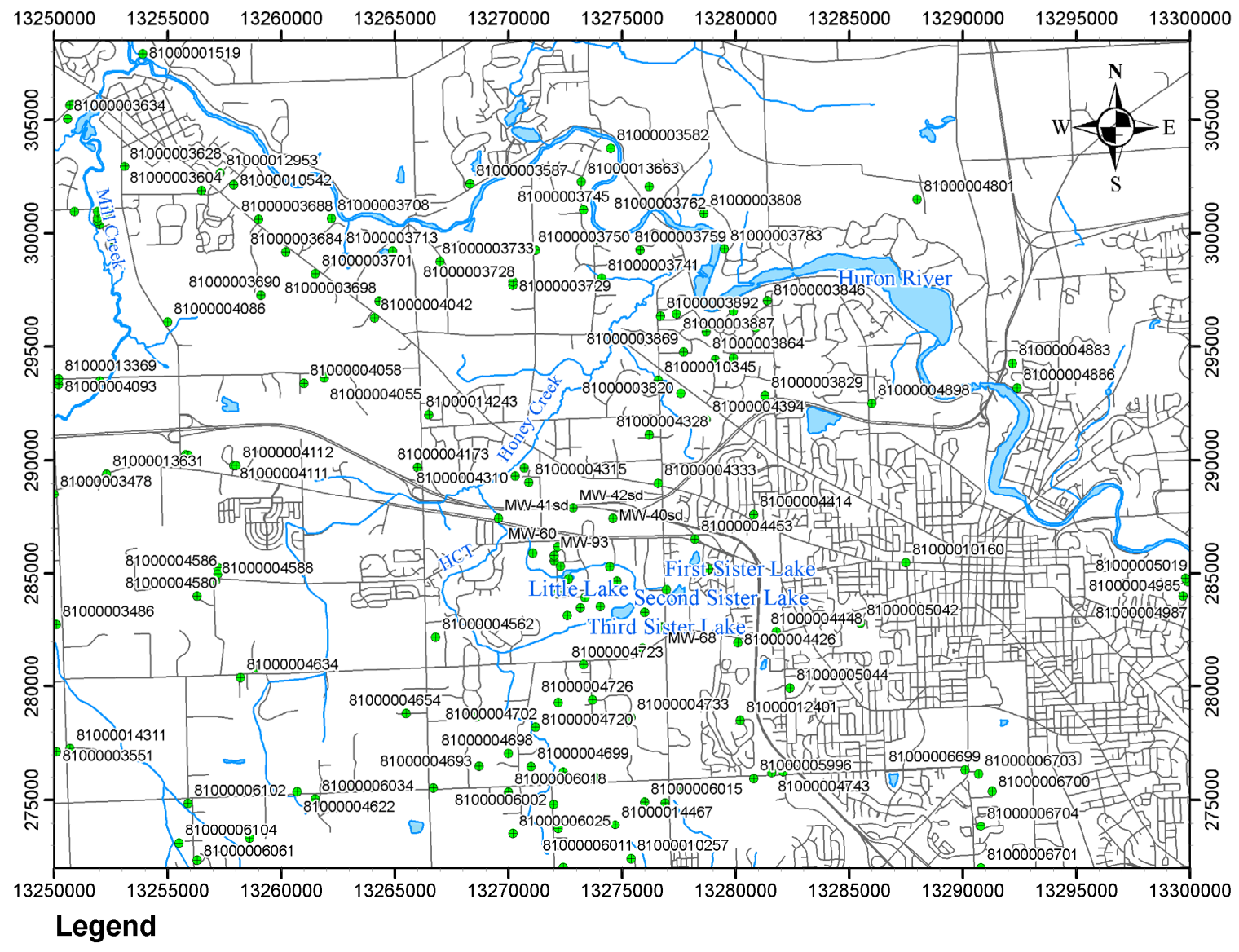

- Boreholes $\longrightarrow$ Streamlines $\square$ Lakes $\square$ Transportation

Figure 2.1 Regional model domain of the conceptual model, Eastings and Northings are in feet.

Table 2.1 Summary of the hydrogeology of the conceptual model

\begin{tabular}{|c|c|c|c|c|c|}
\hline & $\begin{array}{l}\text { Model } \\
\text { Unit }\end{array}$ & Description & Type & Composition & $\begin{array}{l}\text { Elevation range } \\
\text { (feet amsl) }\end{array}$ \\
\hline \multirow[t]{3}{*}{ Top } & 1 & $\begin{array}{l}\text { Upper Confining } \\
\text { Layer (UCL) }\end{array}$ & Confining layer & $\begin{array}{l}\text { Primarily diamicton, } \\
\text { fill, and clay }\end{array}$ & $710-1071$ \\
\hline & 2 & $\begin{array}{l}\text { Upper Aquifer } \\
\text { (UA) }\end{array}$ & $\begin{array}{l}\text { Aquifer (present } \\
\text { under both } \\
\text { confined and } \\
\text { unconfined } \\
\text { conditions) }\end{array}$ & $\begin{array}{c}\text { Primarily sand and } \\
\text { gravel }\end{array}$ & $663-1025$ \\
\hline & 3 & $\begin{array}{l}\text { Lower Confining } \\
\text { Layer (LCL) }\end{array}$ & Confining layer & $\begin{array}{c}\text { Primarily diamicton } \\
\text { and clay }\end{array}$ & $654-953$ \\
\hline Bottom & 4 & $\begin{array}{l}\text { Lower Aquifer } \\
\text { (LA) }\end{array}$ & Aquifer & $\begin{array}{c}\text { Primarily sand and } \\
\text { gravel }\end{array}$ & $600-884$ \\
\hline
\end{tabular}


The hydrogeologic interpretation was based on the reported lithology along with the static water level and previous four-layered conceptual models of Brode (2002) and Cypher (2008). The hydrostratigraphy of the model was defined by using 19 borehole logs from the Cypher (2008) study, coupled with 139 borehole logs (Figure 2.1) and the DEM from the Michigan Geographic Data Library. The materials in each borehole were subdivided into four hydrogeologic classes and assigned the numerical values corresponding to the layer types. The Inversed Distance Weighting (IDW) interpolation method was utilized to delineate layer geometries for the model.

\section{Boundary Conditions}

The Huron River is a main hydrographic feature that influences the regional groundwater system in this area. A discharge of regional groundwater flow to the Huron River was first hypothesized by Healy (2005). At a local scale, the groundwater system is recharged by or discharges to surface water bodies, including lakes and small streams in the study area. Thus, two types of boundary conditions were applied to the model.

All of the perennially hydrographic features, such as Huron River, Mill Creek, First Sister Lake, Second Sister Lake, Third Sister Lake, Honey Creek and its tributaries, were treated as river boundaries (Figure 2.2). When the river attribute is assigned to an object, three river parameters are required: elevation, stage, and conductance. River stage was obtained from the topographic map. River elevation and conductance values are consistent with the study of Cypher (2008). Since there are no data characterizing the river bottom thickness and its vertical hydraulic conductivity has been determined for all surface water bodies in the model domain, the conductance was treated as a fitting parameter in the model. River-bed elevations were approximated with a constant of five feet below the river stage for the Huron River, Mill Creek, and Honey Creek. The Honey Creek tributary (HCT) was assigned the river bed elevation of 2-feet below its river stage. The depth of the First Sister Lake is 12 feet, whereas the Second Sister Lakes is 25 feet. The Third Sister Lake is approximately 55 feet deep (Ball, 1947; Hammer and Stoermer, 1997; Bridgeman et al., 2000; Potzger and Wilson, 1941). The specified parameter values of the river boundaries are shown in Table 2.2. 


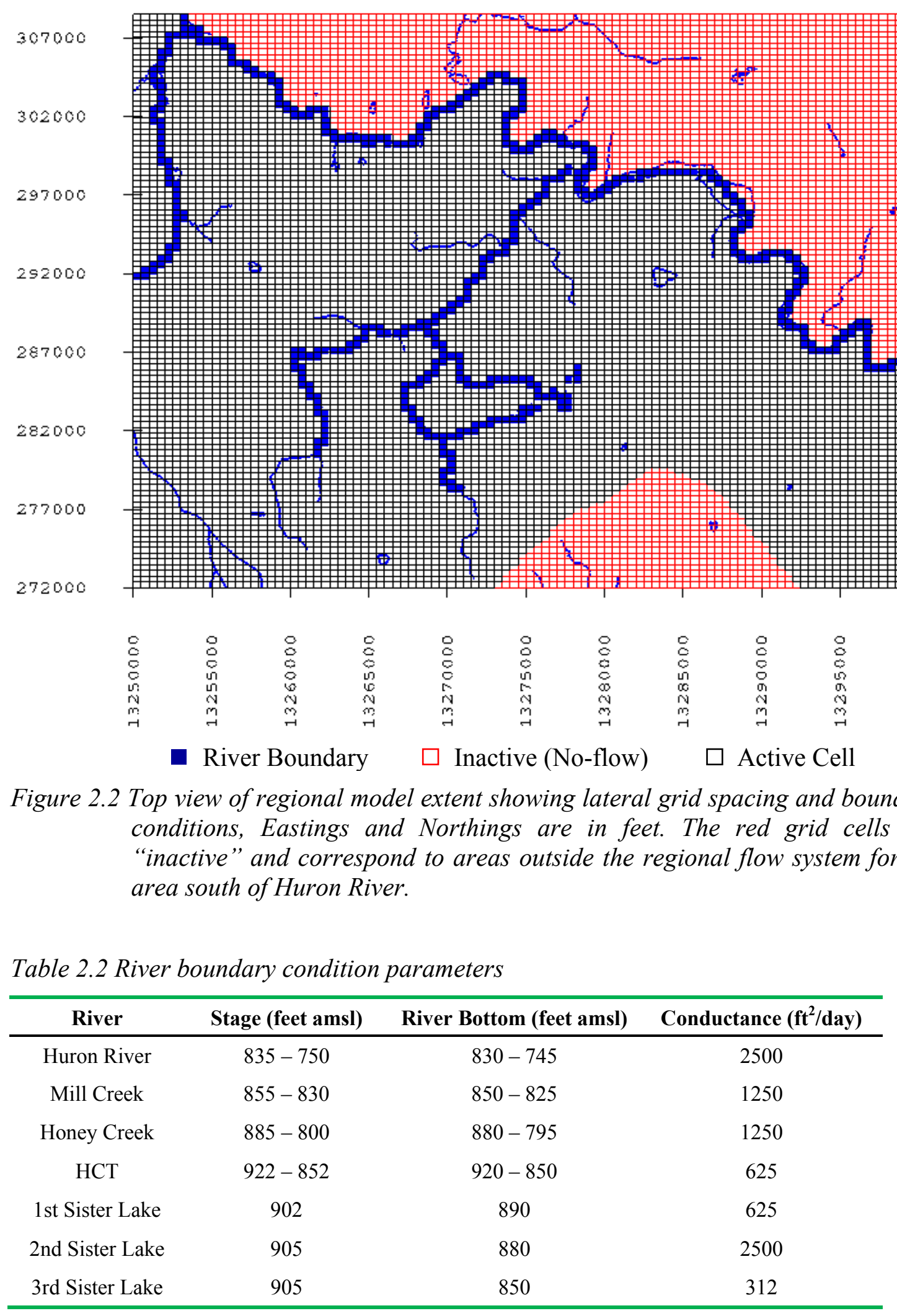


In addition to the river boundary, no-flow boundaries were assigned to the Coldwater Shale bedrock, the western, southern, and eastern borders of the model domain. All cells north of the Huron River were designated inactive since the Huron River is assumed as a ground water divide (Figure 2.2). Nine groundwater recharge zones (Figure 2.3) with respect to different recharge rates ranged from 4 to 12 inches per year were applied across the uppermost active cells. The groundwater recharge data in the study site was obtained from digital map data from the Michigan Geographical Data Library, which contains state-wide estimates of groundwater recharge. Accuracy of the data is $+/-0.092 \mathrm{ft} / \mathrm{yr}$. The digital map data was derived from a study of groundwater recharge, a part of Groundwater Inventory and Mapping Project which is a collaboration of the MDEQ, United States Geological Survey (USGS), and Michigan State University (MDEQ, 2006). The recharge values were calculated from observed baseflow by using a statistical regression technique (MDEQ, 2006). The baseflow is assumed to be equal to groundwater recharge in a shallow glacial aquifer.

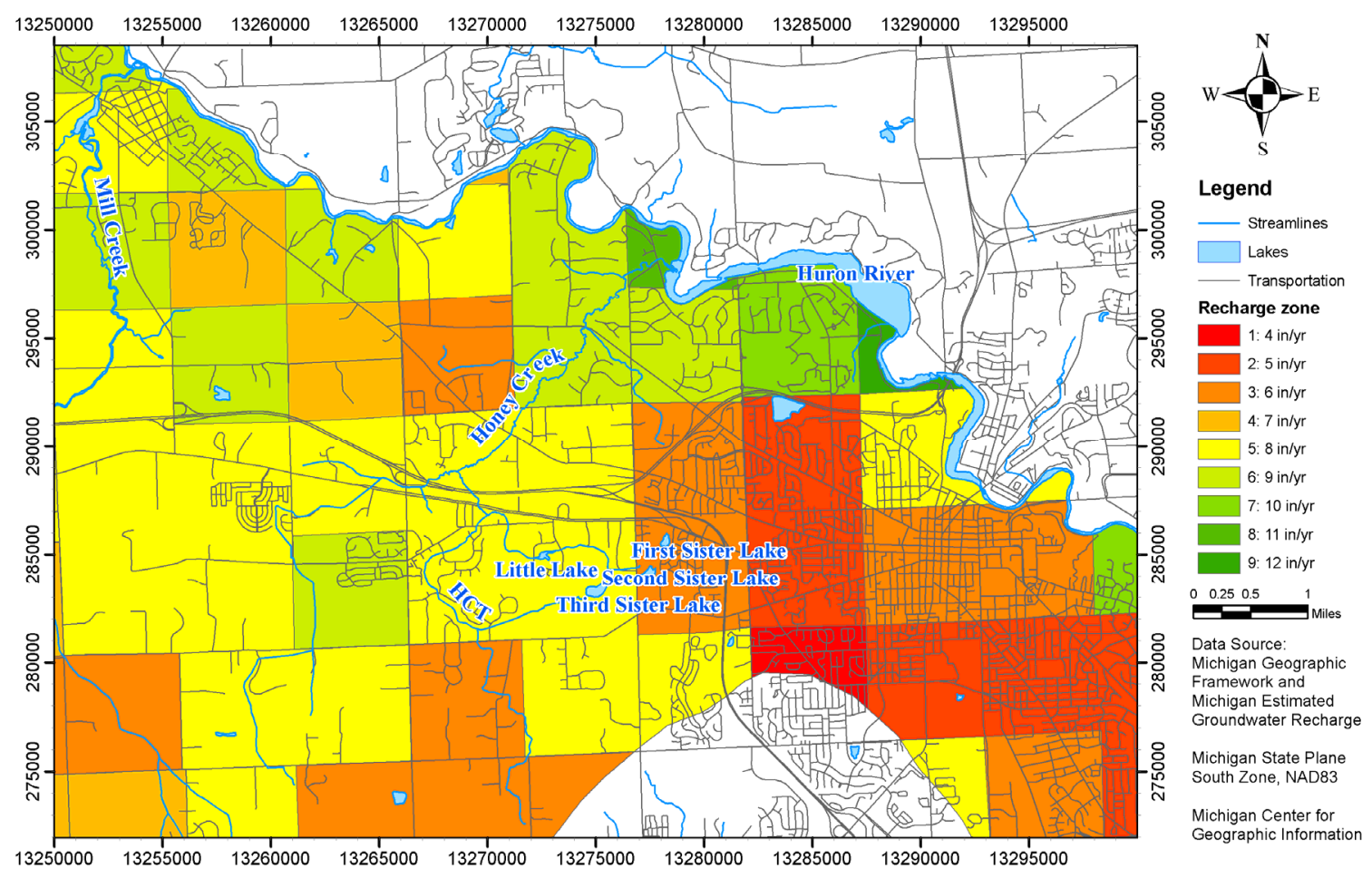

Figure 2.3 Groundwater recharge zones, Eastings and Northings are in feet. 


\section{Regional Flow Model}

\section{Steady State Simulation}

Steady state flow is the condition when heads do not change with time. Therefore, the head gradient, flow velocity, and flow direction are constant. The finite-difference regional model grid consisted of 100 columns and 100 rows. The grid lines are oriented in a north-south, east-west fashion. The uniform grid spacing along the $x$-axis and $y$-axis are 500 and 365 feet, respectively. There are 4 model layers from a depth of 650 to 1,100 feet with a total of 28,048 active cells. The thickness and boundaries of each grid layer was adjusted with regard to the layer ranges of each unit in the conceptual model. Figure 2.2 illustrates the regional model extent and the lateral grid spacing of the model domain.

The parameter values assigned to the model were based on published data and were consistent with the values used by Brode (2002) and Cypher (2008). All parameters except hydraulic conductivity were uniformly assigned to all active cells in the model domain including an assumed porosity of 0.3 , specific yield of 0.2 , and specific storage of $3 \cdot 10^{-6} \mathrm{ft}^{-1}$. Initial groundwater levels for the simulation were set to a small distance below ground surface in order to foster numerical stability. Initial hydraulic conductivity values vary amongst the model layers. One conductivity value was uniformly applied to each layer. The conductivity values used by Brode (2002) and Cypher (2008) in the previous studies were tentatively assigned as the initial parameter values for the calibration simulations. These values are consistent with the values derived from aquifer pumping test results reported by PLS and the published report and data (Fleck, 1980; Freeze and Cherry, 1979; MDEQ, 2004; PLS, 2004; PLS, 2006).

The numerical flow model relied upon the following assumptions:

1. Flow in the aquifer is governed by Darcy's Law of water movement through porous media. Mass and energy were conserved. These assumptions are valid over the scale at which this model is constructed. The solution of the 3-D groundwater flow equation used in MODFLOW is calculated from the following partial differential equation (Harbaugh et al., 2000):

$$
\frac{\partial}{\partial x}\left(K_{x x} \frac{\partial h}{\partial x}\right)+\frac{\partial}{\partial y}\left(K_{y y} \frac{\partial h}{\partial y}\right)+\frac{\partial}{\partial z}\left(K_{z z} \frac{\partial h}{\partial z}\right)+W=S_{s} \frac{\partial h}{\partial t}
$$


where $K_{x x}, K_{y y}$, and $K_{z z}$ are values of hydraulic conductivity along the $x, y$, and $z$ coordinate axes, which are assumed to be parallel to the major axes of hydraulic conductivity $\left(\mathrm{LT}^{-1}\right)$;

$h$ is the potentiometric head (L);

$W$ is a volumetric flux per unit volume representing sources and/or sinks of water, with a negative number represents flow out of the groundwater system, and a positive number for flow in $\left(\mathrm{T}^{-1}\right)$;

$S_{S}$ is the specific storage of the porous media $\left(\mathrm{L}^{-1}\right)$; and $t$ is time (T).

2. Water density and viscosity are constant over time and space.

3. Hydraulic conductivity in each layer is isotropic in both horizontal and vertical directions.

\section{Model calibration}

After running the model under steady-state conditions, the model was calibrated using the potentiometric surface derived from the static water level data (hydraulic heads) in September 1995, which is the time before any significant remedial pumping started at the site (Brode, 2002; Cypher, 2008). The calibration process is necessary to enhance the consistency between the numerical model and the observed system (Anderson and Woessner, 1992). Model calibration is the process of adjusting uncertain model parameters to improve the agreement between the simulated results and the observed data and to increase the model reliability.

In this study, the hydraulic conductivity and recharge were adjusted to modify the head gradient directions and minimize the mean head residual. The remaining parameters were kept constant. The range of hydraulic conductivity values assigned to the aquifer units was 50 to $250 \mathrm{ft} /$ day, which is consistent with glacial outwash sand and gravel deposits (Fetter, 2001). The confining layers were assigned much lower hydraulic conductivity values between 0.005 and $0.5 \mathrm{ft} / \mathrm{day}$, regarding the range of permeability values for till consisting of silty sands, to allow a two-order of magnitude difference in the conductivity between the aquifer and confining units. The recharge values assigned 
during calibration process, as shown in Table 2.3, are within the range of the data accuracy between $\pm 0.092 \mathrm{ft} / \mathrm{yr}$. Water level data collected in September 1995 from 31 wells in the Western Plume area were utilized to create a potentiometric surface map of the Upper Aquifer and to calibrate the steady state simulation. Locations of monitoring wells and the potentiometric surface of the Upper Aquifer are shown in Figure 2.4.

Table 2.3 Groundwater recharge values assigned during calibration process

\begin{tabular}{cccc}
\hline Recharge zone & Initial value (ft/yr) & Minimum value (ft/yr) & Maximum value (ft/yr) \\
\hline 1 & 0.00091 & 0.00066 & 0.00116 \\
2 & 0.00114 & 0.00089 & 0.00139 \\
3 & 0.00137 & 0.00112 & 0.00162 \\
4 & 0.00160 & 0.00135 & 0.00185 \\
5 & 0.00183 & 0.00157 & 0.00208 \\
6 & 0.00205 & 0.00180 & 0.00230 \\
7 & 0.00228 & 0.00203 & 0.00253 \\
8 & 0.00251 & 0.00226 & 0.00276 \\
9 & 0.00274 & 0.00249 & 0.00299 \\
\hline
\end{tabular}

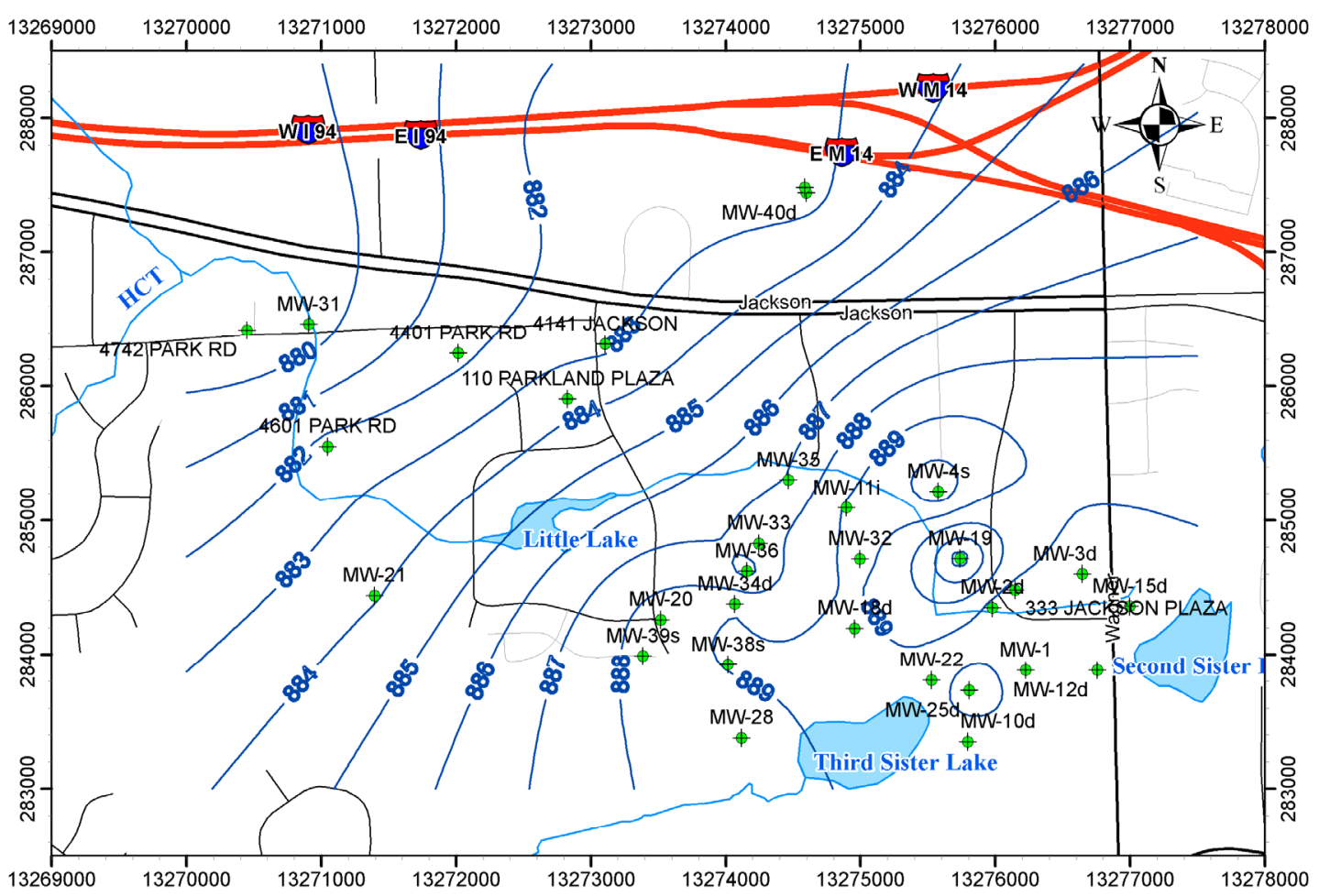

Legend

Potentiometric surface contour $\$$ Monitoring wells Streamlines Lakes

Figure 2.4 September 1995 potentiometric surface map of Upper Aquifer, Eastings and Northings are in feet. 
A trial-and-error technique was used in the calibration process to minimize calibrated statistics. The calibrated statistics, including the mean residual head, mean absolute residual head, and root mean squared (RMS) residual head generated by MODFLOW, are all based on the residual heads. These statistical values are commonly determined to evaluate the model calibration. The residual head is the difference between the simulated head and observed head. The mean residual head is defined as:

$$
\text { Mean residual head }=\frac{1}{n} \sum_{1}^{n}\left(h_{s}-h_{o}\right)_{i}
$$

where $h_{s}$ is the simulated head and $h_{o}$ is the observed head at each observation point. The sum of residuals is divided by the number of data $(n)$, which were 31 observations in this case. The mean absolute residual head is the sum of absolute values of the residuals divided by the number of residuals as defined in equation 2.3 .

$$
\text { Mean absolute residual head }=\frac{1}{n} \sum_{1}^{n}\left|\left(h_{s}-h_{o}\right)_{i}\right|
$$

The mean absolute residual head describes how well a model fits to data while the mean residual head represents the overall bias in calibration. The RMS is calculated by taking a square root of the sum of the square of errors for the observations. It is defined as:

$$
\mathrm{RMS}=\left[\frac{1}{n} \sum_{1}^{n}\left|\left(h_{s}-h_{o}\right)_{i}^{2}\right|\right]^{0.5}
$$

\section{Sensitivity Analysis}

Model sensitivity is a reflection of how much the calibrated simulation would change due to changes in the values of the model inputs. It serves to identify the relative importance of the measured data to the parameter estimation (Hill and Tiedeman, 2007). The sensitivity analysis was performed simultaneously with the calibration process. The analysis consisted of uniformly increasing or decreasing a single model parameter, such as hydraulic conductivity or recharge, and observing the effects on water-level change 
statistics and simulated groundwater discharge to the streams. Only one parameter was changed at a time during the process.

Parameter ESTimation or PEST (Doherty, 2004) was selected for model optimization and sensitivity analysis in this study. PEST is a software package for parameter estimation and uncertainty analysis of complex environmental and other computer models which is alternatively applied as a sensitivity analysis tool in many hydrological models (Baginska et al., 2003; Bahremand and De Smedt, 2008; Tang et al., 2007). PEST estimated the best values of a parameter set by minimizing the weighted sum of the squared residual heads. The sensitivity is simultaneously calculated by using a nonlinear parameter estimation method. The parameter sensitivity value is expressed by relative composite sensitivity, which is a byproduct of the parameter estimation. The relative composite sensitivity of each parameter is useful in determining the effect of the parameters on the model output when these parameters are of different type and magnitudes (Doherty, 2004).

\section{Local Modeling}

Conversion of a regional scale model to a local scale model is a common approach to provide more insight and accurate results for groundwater modeling in a specific locale, particularly in an area where regional groundwater divides and physical boundaries, such as rock outcrops, streamlines, and lakes, are located far beyond a study site. Regional-model grid refinement and hydraulic boundaries, i.e., specified head and no-flow boundary are often utilized to define a new boundary set for constructing a local model (Anderson and Woessner, 1992; Ebraheem et al., 2004).

In this study, a regional-to-local model conversion was accomplished by using tools provided by the GMS program. A local-scale model that occupied a small area within the regional model was developed with grid refinement in a subset of calibrated regional model. Outputs from the regional model simulation, such as computed heads, served as the boundary conditions in the local model. The computed head values from the regional model were assigned as specified head boundaries in the local model. The regional layer data, including top and bottom elevations, and starting heads, were also input to the local model. 
The real-world coordinate of the southwest corner of the local model domain is $(13,267,300 \mathrm{ft}$ East, $281700 \mathrm{ft}$ North) using the Michigan State Plane coordinate system. The coordinate of the northeast corner of the model is $(13,278,300 \mathrm{ft}$ East, 291,800 ft North). Figure 2.5 illustrated the local model domain with respect to the regional model boundary. The local model extent covers the 31 monitoring wells in the Western Plume area and down-gradient area under the range of groundwater flow from the study site toward the Honey Creek. The finite-different model grid consists of 110 columns and 101 rows. The grid lines are oriented in a north-south, east-west fashion. The grid spacing is uniform along the $x$-axis and $y$-axis with a dimension of 100 feet by 100 feet. There are 4 model layers from depth of 650 to 1,100 feet with a total of 28,968 active cells. The thickness and boundaries of each grid layer is obtained from the layer data of the regional model.

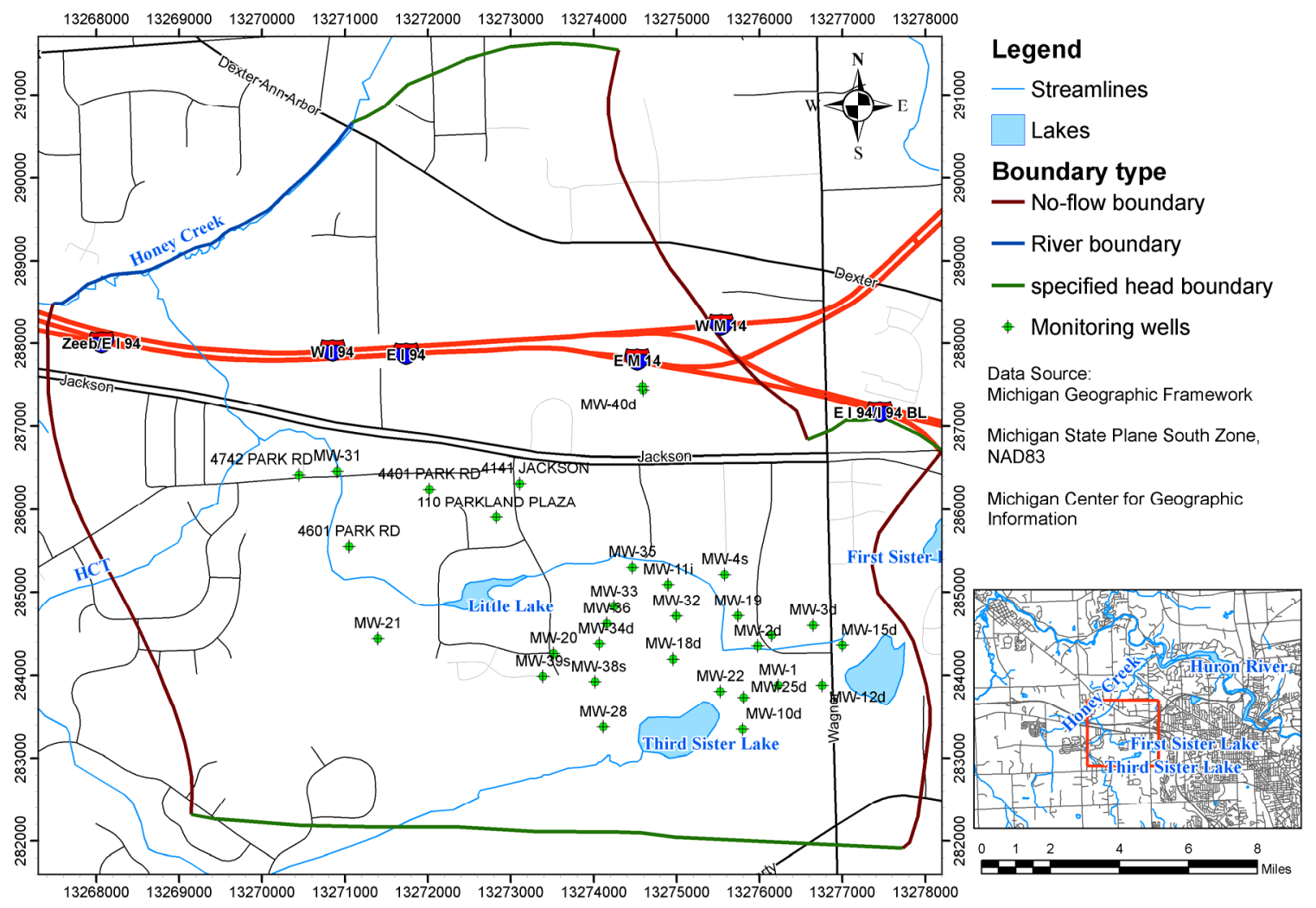

Figure 2.5 Local model extent showing boundary conditions, Eastings and Northings are in feet. 
Hydraulic conductivity in each layer is allowed to be anisotropic in both horizontal and vertical directions. The horizontal anisotropy ${ }^{2}$ of hydraulic conductivity is allowed to range between 0.5 and 1.5 . The vertical hydraulic conductivity for each cell is assigned values that are at or below the horizontal hydraulic conductivity but not less than one-tenth of the horizontal hydraulic conductivity.

After running the model under steady-state conditions, the model was calibrated using the same process as conducted on the regional model. The sensitivity of the local model to the input parameters was also determined as the same manner of the regional model's sensitivity analysis. However, the anisotropy of hydraulic conductivity was an additional parameter included in the local model's analysis.

\section{Transport Modeling}

How dioxane entered the groundwater system in the Western Plume area is still ambiguous. There is no evidence regarding mass-loading history of dioxane in this area. Brode (2002) believed that the contamination of the site occurred between 1967 and 1973 when there was an excess runoff from the PLS site to the lower surrounding area. The concentration of dioxane in the overflow was assumed to be the same as that of the wastewater at approximately $330 \mathrm{mg} / \mathrm{L}$. On the contrary, Cypher (2008) pointed out that the most likely source of dioxane in the Western System area is the Third Sister Lake. However, the assertions of dioxane sources in both studies were based on a transport model with advective transport process only. In this work the transport modeling was more sophisticated, as outlined below.

Diffusion, advection, dispersion and retardation are fundamental mechanisms of solute transport in groundwater (Fetter, 2001). Diffusion is a movement of solutes regarding concentration gradient from a higher concentration area to a lower concentration area (Fetter, 1999; Spitz and Moreno, 1996). Advection is a process in which solutes are carried and transported by flowing groundwater. When the solute is traveling, it can mix with surrounding water along the flow path, resulting in a dilution of

${ }^{2}$ Horizontal anisotropy is defined as the ratio of the hydraulic conductivity in the $x$-direction relative to the hydraulic conductivity in the $y$-direction. 
the plume. This process is called dispersion. Retardation is a process in which solution movement is slowed down by sorption and chemical reaction to aquifer materials. The primary processes of contaminant transport in a groundwater system can be represented by the following partial differential equation (Zheng and Wang, 1999):

$$
\frac{\partial(\theta C)}{\partial t}=\frac{\partial}{\partial x_{i}}\left(\theta D_{i j} \frac{\partial C}{\partial x_{j}}\right)-\frac{\partial}{\partial x_{i}}\left(\theta v_{i} C\right)+q_{s} C_{s}+\sum R_{n}
$$

where

$\theta=$ porosity of the subsurface medium, dimensionless

$C=$ dissolved concentration $\left(\mathrm{ML}^{-3}\right)$

$t=$ time, $\mathrm{T}$

$x_{i, j}=$ distance along the respective Cartesian coordinate axis $(\mathrm{L})$

$D_{i j}=$ hydrodynamic dispersion coefficient tensor $\left(\mathrm{L}^{2} \mathrm{~T}^{-1}\right)$

$v_{i}=$ seepage or linear pore water velocity $\left(\mathrm{LT}^{-1}\right)$; it is related to the specific discharge or Darcy flux through the relationship, $v_{i}=q_{i} / \theta$

$q_{s}=$ volumetric flow rate per unit volume of aquifer representing fluid sources (positive) and sinks (negative) $\left(\mathrm{T}^{-1}\right)$

$C_{s}=$ concentration of the source or sink flux $\left(\mathrm{ML}^{-3}\right)$

$\Sigma R_{n}=$ chemical reaction term $\left(\mathrm{ML}^{-3} \mathrm{~T}^{-1}\right)$.

MT3DMS was utilized in this study because of its capability to develop a transport model concerning all above processes (Zheng and Wang, 1999). The program requires the following input parameters with respect to its basic transport package in order to simulate the dioxane transport in this area:

\section{Advection}

Advection is commonly the most influencing process on the contaminant transport, particularly in highly permeable materials such as sand and gravel. The advance of solute by advective transport is directly related to the rate of groundwater flow. According to the Darcy's law, the rate of groundwater movement in porous media can be determined in term of average linear velocity. The average linear velocity can be calculated from the following equation: 


$$
v_{x}=\frac{K}{n_{e}} \frac{d h}{d l}
$$

where $v_{x}$ is the average linear velocity $\left(\mathrm{LT}^{-1}\right), K$ is hydraulic conductivity $\left(\mathrm{LT}^{-1}\right), n_{e}$ is effective porosity (dimensionless), and $d h / d l$ is hydraulic gradient $\left(\mathrm{LL}^{-1}\right)$. The advective rate is determined by first solving the groundwater flow model, in this case MODFLOW2000, and using the spatial distribution of $h$ in Equation 2.6 to calculate the velocity field.

\section{Dispersion}

Schulze-Makuch (2005) provided a formula to calculate the longitudinal dispersivity for various types of aquifer media. This relationship of the longitudinal dispersivity was developed by using a statistical analysis of data from laboratory experiments, aquifer tests, and modeling in different scales and materials. The longitudinal dispersivity can be calculated from:

$$
\alpha=c(L)^{m}
$$

where

$\alpha$ is longitudinal dispersivity (L)

$c$ is a parameter characteristic of a geological medium $\left(\mathrm{L}^{1-m}\right)$

$L$ is the flow distance $(\mathrm{L})$

$m$ is the scaling exponent (Schulze-Makuch, 2005).

A rule-of-thumb ratio (Fetter, 1999) of horizontal transverse dispersivity to longitudinal dispersivity of 0.1 was initially assigned to the dispersion package. The MT3DMS also requires the ratio of vertical transverse dispersivity to longitudinal dispersivity in which the default value of 0.01 was primarily used.

\section{Diffusion}

Molecular diffusion and mechanical dispersion are most commonly considered together since mathematically they are treated the same in the governing equation for contaminant transport. The association of these two processes in groundwater flow is known as hydrodynamic dispersion (Fetter, 1999). A relationship between the mechanical 
mixing and diffusion for horizontal flow is represented by a factor called hydrodynamic dispersion coefficient, $D_{L}$.as shown in the following equation:

$$
D_{L}=\alpha_{L} v_{i}+D^{*}
$$

where

$D_{L}$ is the longitudinal coefficient of hydrodynamic dispersion $\left(\mathrm{L}^{2} \mathrm{~T}^{-1}\right)$

$\alpha_{L}$ is longitudinal dynamic dispersivity (L)

$v_{i}$ is average linear velocity in the $i$ direction $\left(\mathrm{L} \mathrm{T}^{-1}\right)$

$D^{*}$ is effective molecular diffusion coefficient $\left(\mathrm{L}^{2} \mathrm{~T}^{-1}\right)$.

PLS (2004) reported the effective molecular diffusion coefficient for dioxane in water, at the ambient groundwater temperature, of $0.000905 \mathrm{ft}^{2} /$ day in the study of the Unit E plume (or comparable to the Lower Aquifer in this study). The magnitude of the coefficient is very small when compared to the magnitude of the multiplication of the dispersivity and the velocity. Implicitly, the diffusion would not have any significant impact on the degree of dispersion. Therefore, the diffusion was not important in any of these simulations.

\section{Retardation}

According to the study of dioxane fate and transport conducted by Fishbeck, Thompson, Carr \& Huber, Inc. (FTC\&H) in 2004, an assumed retardation factor of 1.3 was used in the model simulation of Unit E aquifer, the Lower Aquifer (PLS, 2004). The retardation factor of 1.6, the highest value estimate for dioxane (Priddle and Jackson, 1991), was however applied in this study to accommodate a longer residence (the worst case) of dioxane in the system. To date the contamination in the site has existed for more than two decades after it was discovered, or 40 years since the dioxane was first used by PLS. In addition, the simulation was conducted using a conservative approach. Therefore biodegradation was not included in the simulation to allow for a long-time persistence of the contamination.

The chemical reaction package in the GMS program requires three parameters for simulating retardation: porosity, particle density, and sorption constant. A typical particle

density of $2.65 \mathrm{~g} / \mathrm{cm}^{3}$ was assumed in this study. The distribution coefficient, $K_{d}$ (or first 
sorption constant), was calculated from the equation 2.8 based on the retardation factor and bulk density.

$$
R=1+\frac{(1-n) \rho_{s} K_{d}}{n}
$$

where

$R$ is retardation factor (dimensionless)

$\rho_{s}$ is the soil particle density $\left(\mathrm{ML}^{-3}\right)$

$K_{d}$ is distribution coefficient (slope of the isotherm) $\left(\mathrm{L}^{3} \mathrm{M}^{-1}\right)$

$n$ is porosity (Spitz and Moreno, 1996).

\section{Potential Sources of Contamination}

The PLS facility is the most probable source of dioxane in this area. However, it is still uncertain how dioxane entered the groundwater. Dioxane was used by PLS for two decades, from 1966 to 1986 . The wastewater was disposed of using treatment ponds, spray irrigation, and deep-well injection. Both Little Lake and Third Sister Lake have been suggested as the source locations of the Western Plume (Brode, 2002; Cypher and Lemke, 2009). Thus, a starting concentration of $200 \mathrm{ppb}$, which is approximately the highest value monitored in the lakes, was simulated at the location of the Little Lake and Third Sister Lake to determine the pathway of dioxane until 1997 when the pumping remediation began. In order to evaluate the potential source of the contamination in the Western Plume area, a delineation map of the April 1988 dioxane concentration data was established as shown in Figure 2.6 


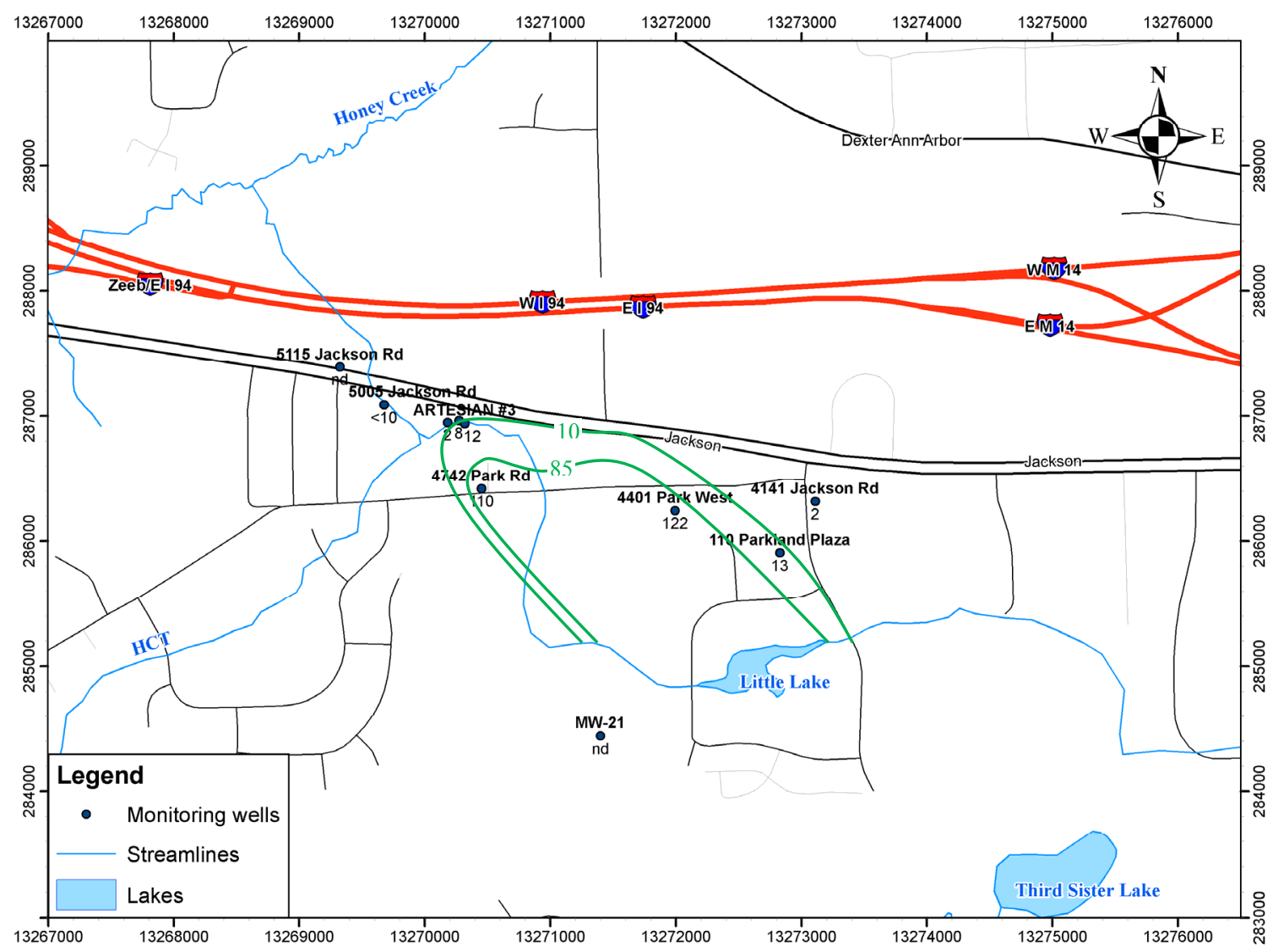

Figure 2.6 April, 1988 delineation map of dioxane concentration in Upper Aquifer. Isoconcentration contours (green lines) are in ppb. Eastings and Northings are in feet. 


\section{Results}

The study of dioxane transport consists of multiple aspects, including data analysis and numerical modeling. Data analysis were undertaken in order to better understand the aquifer system and contaminant transport. Most of all the required data were obtained from public sources generally provided by the state government. The data were collected and properly processed for use in the modeling. Then the numerical groundwater models were constructed to simulate the groundwater flow and historical plume migration based on the conceptual model interpreted from all available data and information. The results from all above processes are presented here in Chapter 3 and will be discussed in the Discussion section (Chapter 4)

\section{Conceptual model}

The conceptual hydrogeological model includes two laterally continuous confining units bounding two laterally extensive aquifers. This interpretation of a system of confined aquifers was based on previous studies in the area. The goal of this work is to demonstrate the use of publically available data in developing and testing models of groundwater flow and contaminant transport, and it was desired to use the previous studies as the baselines for comparison. Therefore it was important to maintain as much similarity as practical with the conceptual models of the previous authors.

The IDW interpolation technique was utilized to establish the subsurface geometry. The hydrogeology of the study area resulted from the interpretation reveals a topographic high on top elevation of the Lower Confining Layer oriented in a northeastsouthwest direction (Figure 3.1). This important feature may influence the connection of groundwater flow between the Core area and the Western Plume area and will be discussed later in the Discussion section (Chapter 4). 


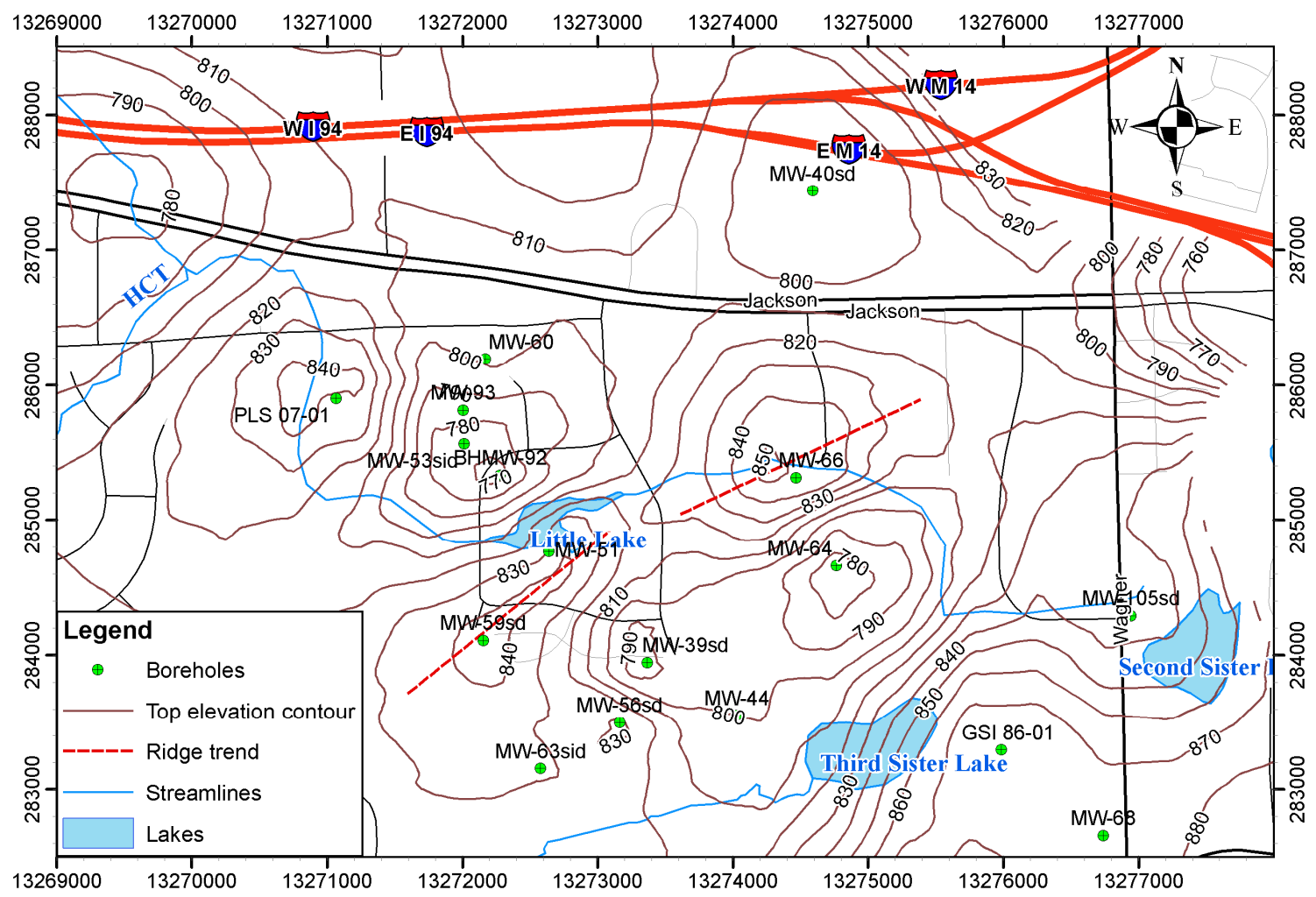

Figure 3.1 Top elevation contour map of the Lower Confining Layer. The dashed red lines denote the topographic higher parts of the LCL.

\section{Regional Flow Model}

\section{Steady State Flow}

The steady state simulation produced the potentiometric surface shown in Figure 3.2, which is similar to the measured potentiometric surface of the Upper Aquifer (Figure 2.4). The groundwater generally flows across the Western Plume area toward Honey Creek in the northwest direction. However, the main direction of regional groundwater flow is north and northeast toward the Huron River. The average linear velocity of groundwater flow was calculated to be approximately $1.15 \mathrm{ft} / \mathrm{day}$, which is consistent with the aquifer performance test conducted in June 1993 (Alpha Geosciences, 1993). 


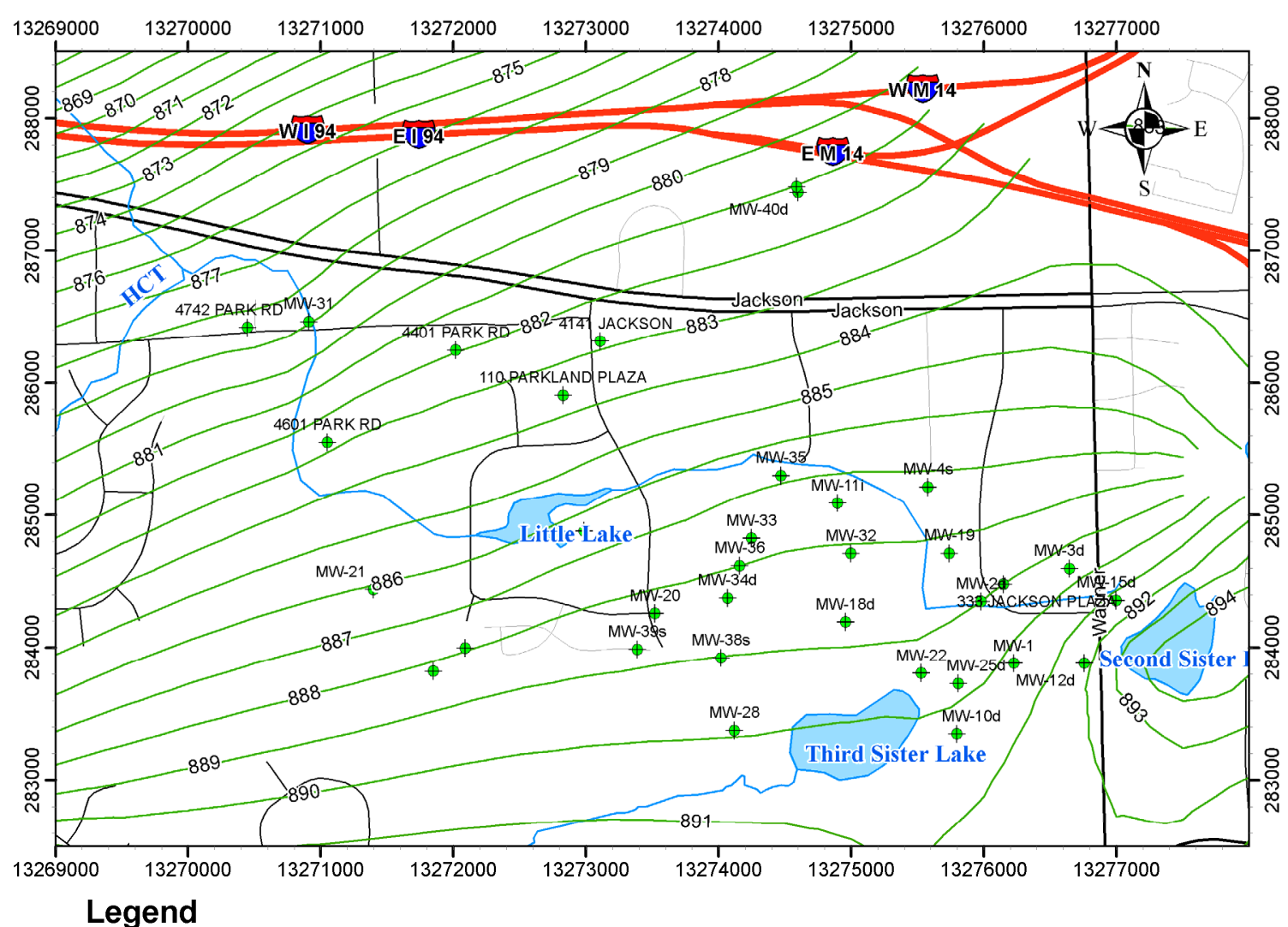

Legend

- Simulated water levels Monitoring wells — Streamlines Lakes

Figure 3.2 Steady state potentiometric surface map (regional model layer 2, contours are in feet amsl, Eastings and Northings are in feet).

\section{Model Calibration}

Model calibration is necessary to improve the accuracy and reliability of the simulation. The head residuals were minimized in the calibration process. The analysis was performed by minimizing the difference in heads between the model simulation and 31 observations in September 1995. Calibration statistics, groundwater flow direction (qualitatively), and flow budget comparisons were also considered in the calibration evaluation. Figure 3.3 represents the correspondence between the observed head and computed head. The result from the calibration process including residual heads and calibration statistics is provided in Figure 3.4. 
Computed vs. Observed Values

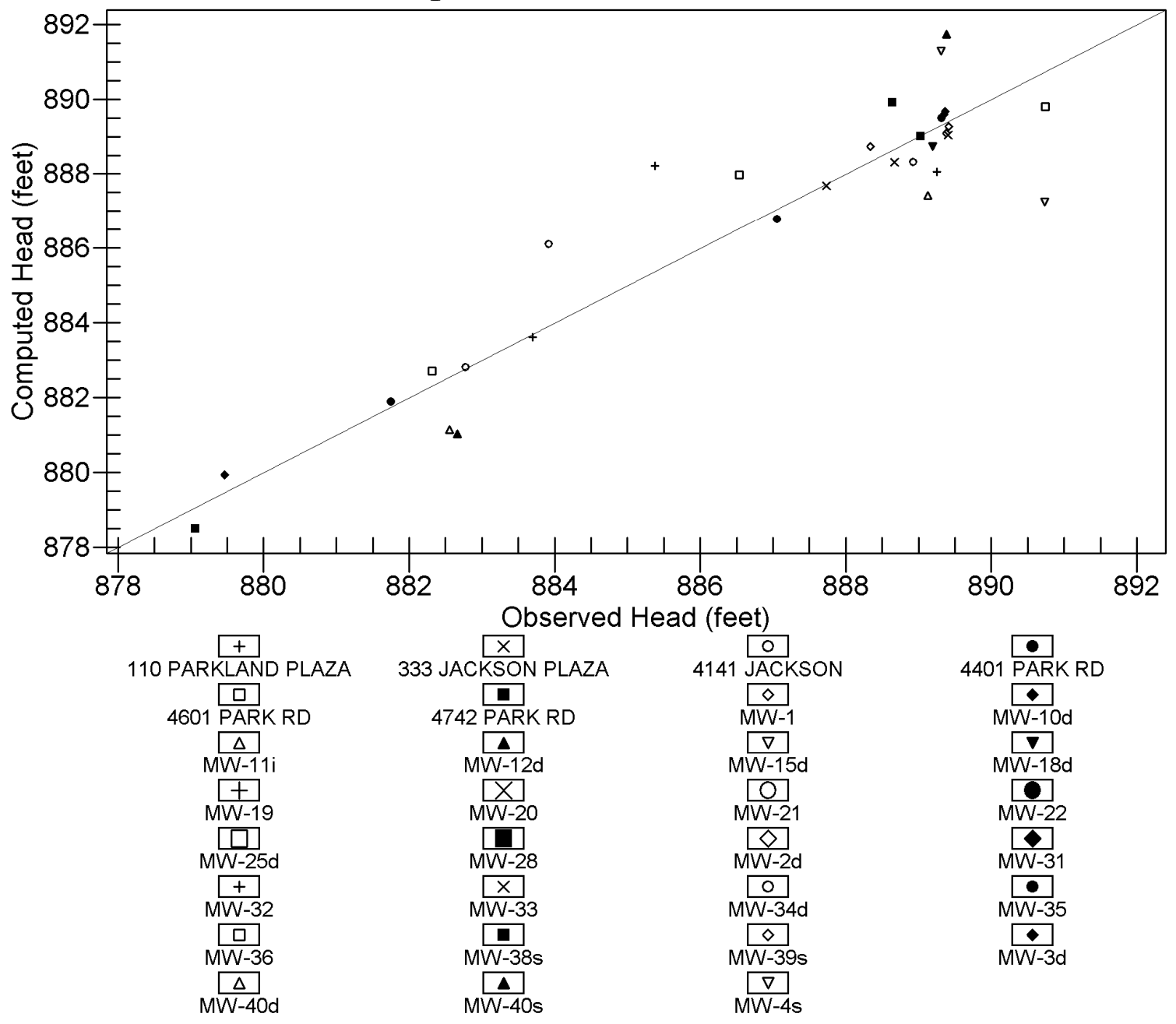

Figure 3.3 Plot of computed versus observed heads for Upper Aquifer unit in regional flow model. See Figure 3.2 for well locations. 




Figure 3.4 Plot of residual versus observed heads for Upper Aquifer unit in regional flow model. See Figure 3.2 for well locations. 
The interaction between the groundwater system and surface water, including Huron River, Mill Creek, Honey Creek and its tributaries, were also monitored. The estimated groundwater discharge of $8 \cdot 10^{-6} \mathrm{ft}^{3} /$ day to Huron River was reported by Cypher (2008). Nevertheless, only half of the flux was considered as the total groundwater flow to the Huron River regarding the inactive cells north of the Huron River. The simulated groundwater flux into the Huron River is $1.1 \cdot 10^{-6} \mathrm{ft}^{3} /$ day and slightly consistent with the reported value. In addition, the simulated flux to Mill Creek was compared with streamflow data from the National Water Information System. In 2003, the relationship between groundwater and surface water along Honey Creek in Washtenaw County were investigated by the USGS and the city of Ann Arbor, Michigan (Healy, 2005). Stream flows were monitored from June to October at 18 different locations. The simulated flux into the Honey Creek and its tributaries were consistent with the observed values in this report. The overall water budget for the regional aquifer system was also determined and is summarized in Table 3.1. Recharge comprises the single largest inflow (99.96 percent of total inflow), whereas all the outflow is groundwater discharge to river boundaries. The difference between the inflow and outflow of the system is only $0.0002 \%$.

\begin{tabular}{lcc}
\multicolumn{3}{l}{ Table 3.1 Simulated water budget for the calibrated regional flow model } \\
\hline Flow $\mathbf{~} \mathbf{n}\left(\mathbf{f t}^{\mathbf{3}} / \mathbf{y r}\right)$ & Flow Out $\left(\mathbf{f t}^{\mathbf{3}} / \mathbf{y r}\right)$ \\
\hline Sources/Sinks & & \\
$\quad$ Rivers & 92652 & -2131090 \\
$\quad$ Recharge & 2038442 & 0.0 \\
Total Source/Sink & 2131094 & -2131090 \\
Summary & $\mathbf{I n}$ - Out & $\mathbf{\%}$ difference \\
Sources/Sinks & 4 & 0.00021 \\
\hline
\end{tabular}

Initial Parameter values assigned to the model were tentatively based on the values used in the previous studies (Brode, 2002; Cypher, 2008). These parameters, except for the conductances in the river boundaries, were then adjusted during the calibration process to lower the difference between the simulated heads and the observed heads and to produce groundwater flow toward the northwest in the Western System area. The conductance of the Second Sister Lake was suggested to be the primary key for the 
direction of groundwater flow in this area (Cypher, 2008) and was also calibrated. However, the initial value assigned to the regional model was found to be proper. The calibrated parameter values, including the hydraulic conductivities and the recharge rates, are listed in Table 3.2

Table 3.2 Summary of calibrated parameter values for the regional model

\begin{tabular}{ccc}
\hline Parameter & Description & Value (ft/day) \\
\hline K1 & Hydraulic conductivity of UCL & 0.019 \\
K2 & Hydraulic conductivity of UA & 99 \\
K3 & Hydraulic conductivity of LCL & 0.085 \\
K4 & Hydraulic conductivity of LA & 160 \\
R1 & Recharge rate zone 1 & 0.000662 \\
R2 & Recharge rate zone 2 & 0.001392 \\
R3 & Recharge rate zone 3 & 0.001415 \\
R4 & Recharge rate zone 4 & 0.001346 \\
R5 & Recharge rate zone 5 & 0.001574 \\
R6 & Recharge rate zone 6 & 0.002304 \\
R7 & Recharge rate zone 7 & 0.002031 \\
R8 & Recharge rate zone 8 & 0.002259 \\
R9 & Recharge rate zone 9 & 0.002989 \\
\hline
\end{tabular}

\section{Sensitivity Analysis}

Sensitivity analysis was conducted to determine the sensitivity of the calibrated model to changes in model inputs by using PEST. Weighted sum-of-squared errors between observed head and computed head and the best set of parameters were calculated and recorded by PEST during iterative simulation. The parameter sensitivity is represented in terms of a relative composite sensitivity. The higher value of the relative composite sensitivity reflects the greater impact of parameter value changes to the overall model output. The relative sensitivity of each parameter calculated by PEST is shown in Figure 3.5. The relative composite sensitivity is a composite change in model output due to the parameter value variation. 


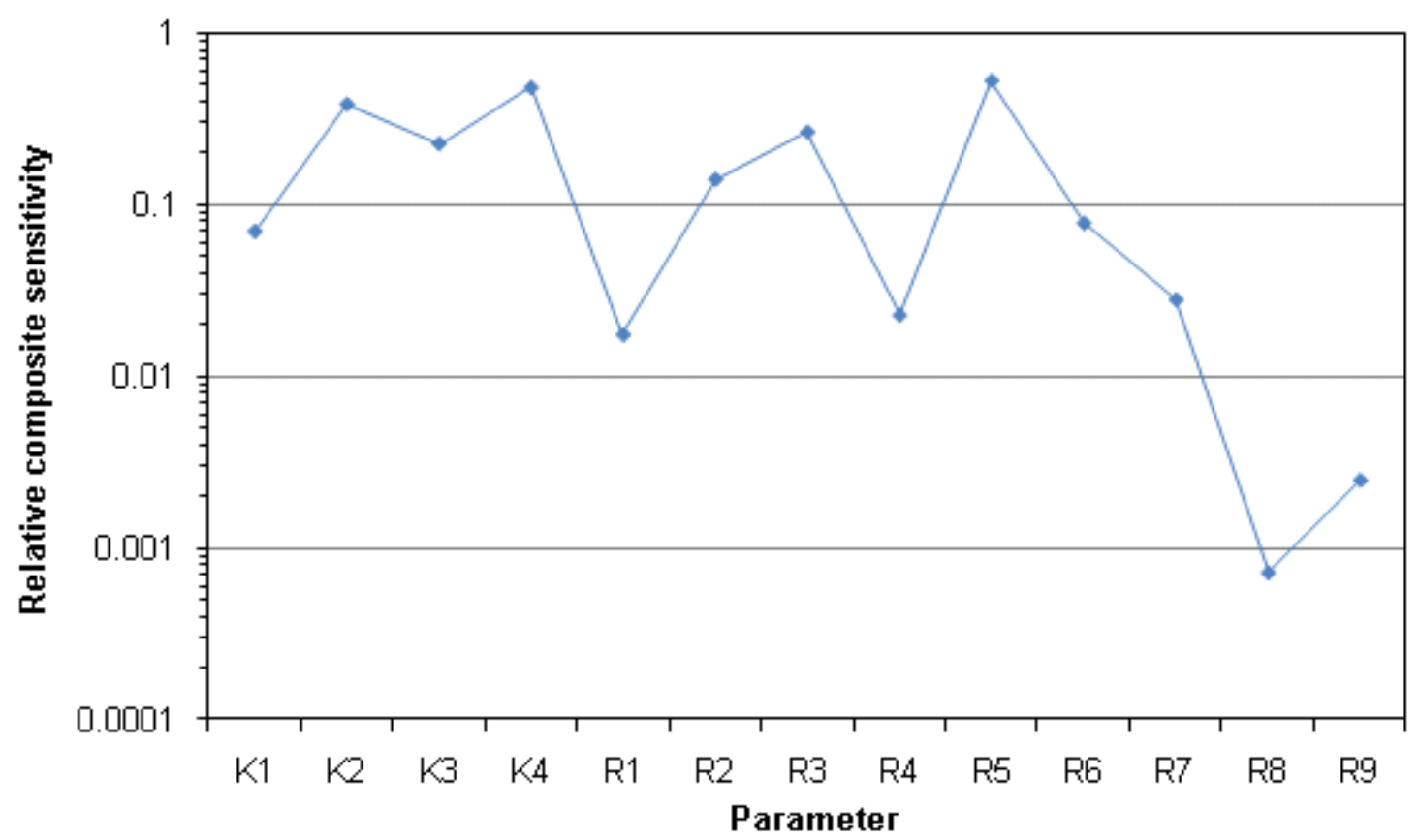

Figure 3.5 Relative composite sensitivity of calibrated parameters.

The most sensitive parameter is the recharge rate for zone 5 (R5 in Figure 3.5), which covers the majority of the Western Plume area, whereas the hydraulic conductivity of the Lower Aquifer (K4) is the second most important. The calibrated regional model is least sensitive to changes in recharge rate for zone 8 (R8). Overall the model is sensitive to changes in recharge rates, particularly for the zones in the vicinity of the study area. Changes in hydraulic conductivity produce increased residual heads in every observation well. However, changes in hydraulic conductivity values in aquifers have more effects on the simulation than the confining units. One order of the magnitude change in the conductivity of the aquifers resulted in a significant increase of the Mean Absolute Residual. Flow direction and head gradient in the upper aquifer significantly changes with adjustment one order of magnitude of the Lower Aquifer's hydraulic conductivity. In contrary, adjustment of the Upper Aquifer's hydraulic conductivity has little effect on flow direction.

\section{Local Flow Model}

A local flow model was constructed with grid refinement based on the result from the Regional flow model. The local model primarily covers the vicinity of the Western 
Plume and its down-gradient area. All of the regional model inputs were adopted for the local model. The simulated water levels of the regional flow model were applied as starting heads for the local flow model. Two of the computed head values from the regional model were assigned as specified head boundaries to mark the boundaries of the local model. Consequently, steady-state simulation of the local model produced a fairly uniform head gradient similar to regional model result (Figure 3.6).

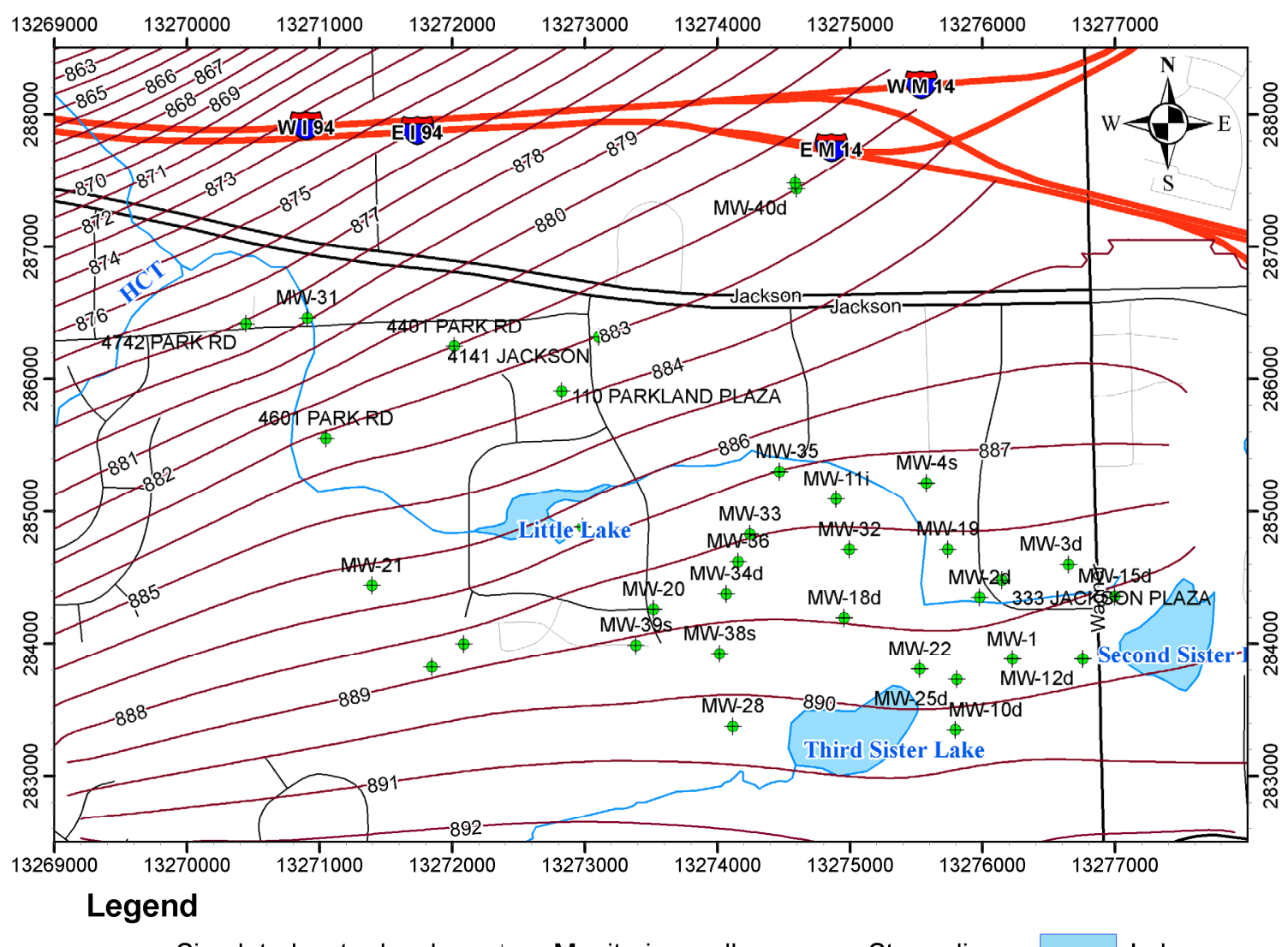

Figure 3.6 Steady state potentiometric surface map (local model layer 2, contours are in feet amsl, Eastings and Northings are in feet).

The local model was calibrated using the same manner as the regional model. However, the calibrated local model possesses lower residual heads than calibrated regional model. The correspondence between the observed heads and computed heads is illustrated in Figure 3.7. The calibrated simulation produced very slight underestimates in water levels with a mean residual of $-0.01 \mathrm{ft}$. Figure 3.8 provides the result from the calibration process including the residual heads and calibration statistics. 
Computed vs. Observed Values



Figure 3.7 Plot of computed versus observed heads for Upper Aquifer unit in local flow model. 


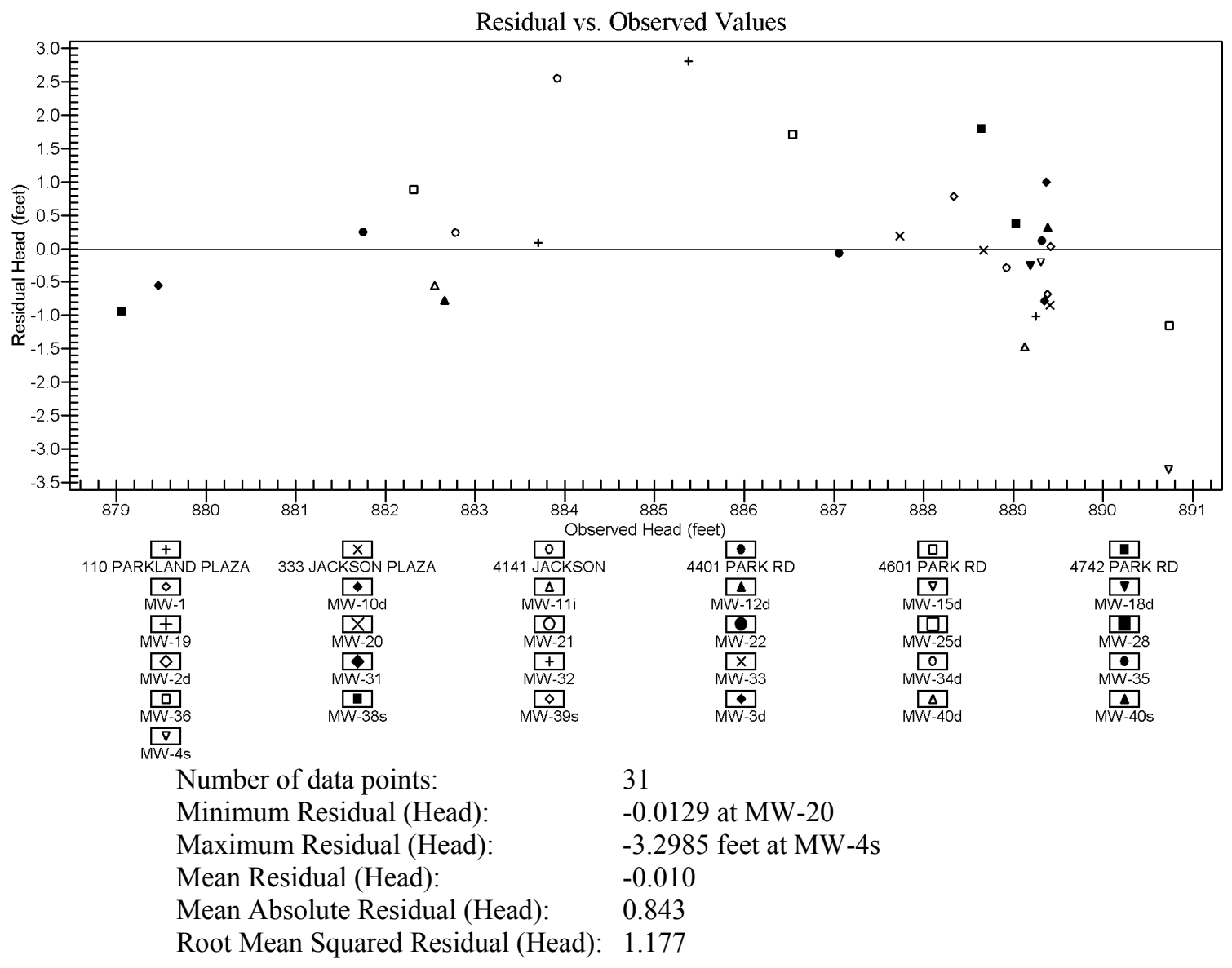

Figure 3.8 Plot of residual versus observed heads for Upper Aquifer unit in regional flow model.

Simultaneously, sensitivity analysis was executed during the calibration process. Parameter sensitivity was estimated by PEST program and expressed in terms of relative composite sensitivity. The higher relative sensitivity value reflects more impact of changes in parameter to model output. The residual heads is increasing when the hydraulic conductivity for layer 3 , the recharge rate for zone 5 , and the hydraulic conductivity for layer 2 changes, respectively. In contrast, the local model is least sensitive to the hydraulic conductivity for model layer 1 . The relative sensitivity values and the calibrated parameter values including the hydraulic conductivities and the recharge rates are listed in Table 3.3. 
Table 3.3 Summary of calibrated parameter values and sensitivities for the local model

\begin{tabular}{cccc}
\hline Parameter & Description & Value & Sensitivity \\
\hline K1 & Hydraulic conductivity of UCL (ft/day) & 0.27 & $8.87\left(10^{-4}\right)$ \\
K2 & Hydraulic conductivity of UA (ft/day) & 92 & $2.66\left(10^{-1}\right)$ \\
K3 & Hydraulic conductivity of LCL (ft/day) & 0.005 & $1.77\left(10^{-1}\right)$ \\
K4 & Hydraulic conductivity of LA (ft/day) & 160 & $2.61\left(10^{-2}\right)$ \\
R3 & Recharge rate zone 3 (in/yr) & 0.00162 & $2.66\left(10^{-2}\right)$ \\
R5 & Recharge rate zone 5 (in/yr) & 0.00208 & $2.48\left(10^{-1}\right)$ \\
\hline
\end{tabular}

\section{Transport model}

A MT3DMS simulation was performed using the GMS program to create a transport model of dioxane from two potential source locations of contamination in the Western Plume area: Little Lake and Third Sister Lake (Brode, 2002; Cypher and Lemke, 2009). A set of parameters was required for the simulation such as stress period, longitudinal dispersivity, starting concentration, porosity and distribution coefficient. MT3DMS uses the groundwater flow solution from MODFLOW2000.

The longitudinal dispersivity was calculated from Schulze-Makuch's equation (Schulze-Makuch, 2005). The formula requires two parameters to be assigned for the calculation: a parameter characteristic for a geological medium and flow distance. Since glacial drift is the lithologic setting of the study area, a parameter value of unconsolidated category was applied for the geologic media factor. The flow distance is a horizontal length between a groundwater source and sink, which is the source location of dioxane and the Honey Creek, respectively. The flow distance was measured along the axis of dioxane-plume travel during the first tranport simulation with only advective process. The model was initially simulated with only one stress period from January 1, 1966 to January 1,1997 . The total length of time is 11,323 days (31 years). A porosity of 0.3 was utilized and assigned as a fixed parameter for all model layers. The calculation resulted in the longitudinal dispersivity of 44 feet. This dispersivity value was also used as a fixed parameter during the calibration process.

\section{Potential Sources of Contamination}

The initial transport simulation resulted in a support of the hypothesis for the Little Lake as a source location of contamination in the Western Plume area. Simulated 
dioxane plume from the Little Lake source travels through the center of the Western Plume area and consistent with observed concentration data (Figure 3.9). The plume exits the aquifer system at the Honey Creek. Conversely, the plume pathway simulated from the Third Sister Lake is off-center of the Western Plume system compared to its position in the April 1988 maps (Figure 2.6). The plume advances primarily northward to the downgradient area (Figure 3.9).

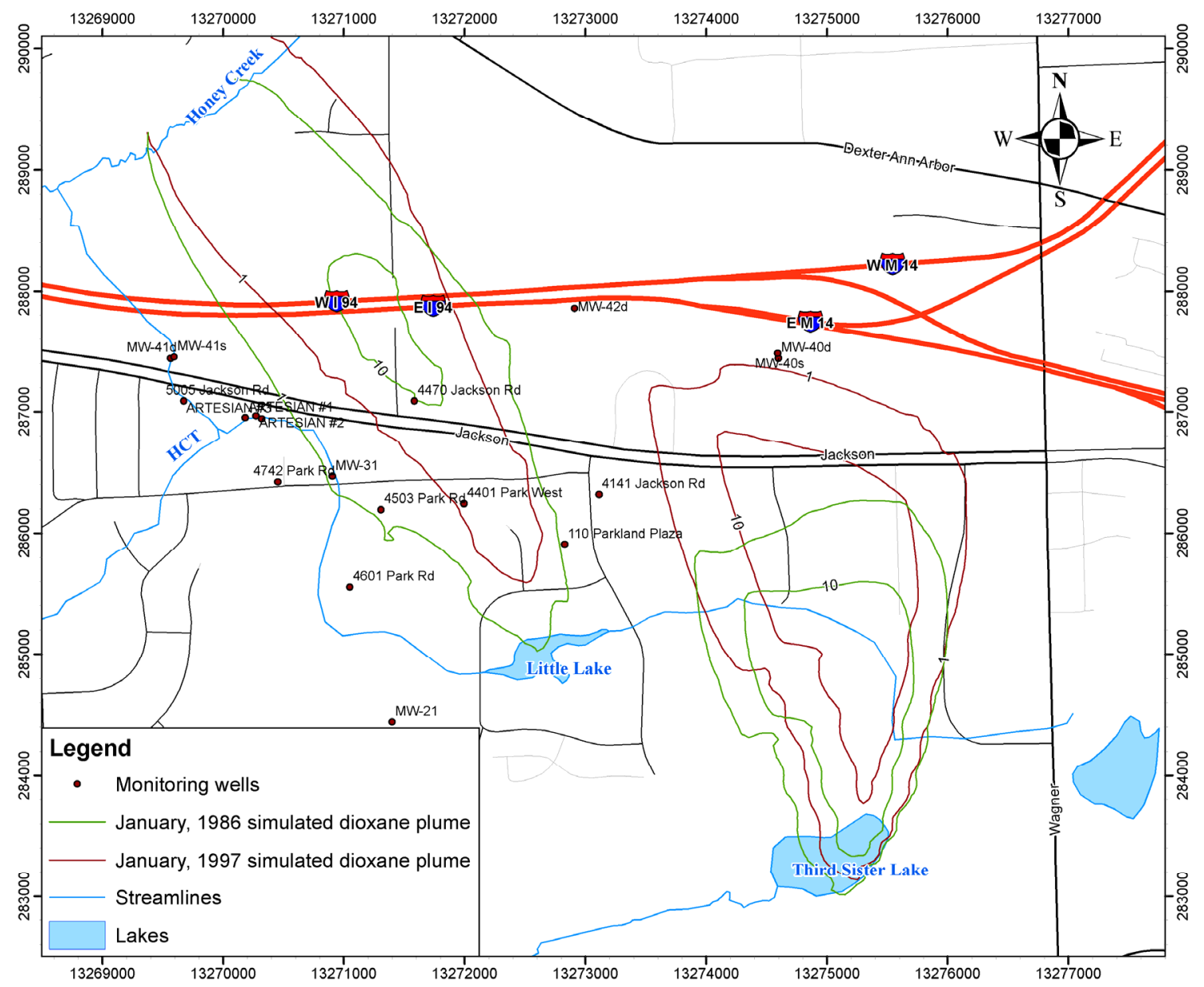

Figure 3.9 Simulated plume delineation map in Lower Aquifer with initial condition (isoconcentration contours are in ppb, Eastings and Northings are in feet).

The transport model of dioxane from the Little Lake and its downstream movement was calibrated using groundwater quality data collected between 1986 and 1996. The model was run under a total of 38 stress periods with respect to the groundwater quality sample dates and the assumed periods contamination released to the system. Dioxane is assumed to be distributed to the Honey Creek via overland flow, 
presumably occuring in years which the annual precitation data was above the average (Figure 1.5). Hence, a specified concentration of $200 \mathrm{ppb}$ was assigned to the proper stress period regarding the annual precipitation data between 1966 and 1986. The transport model was calibrated with concentration data from 18 monitoring wells. The concentration data exceeed the $85 \mathrm{ppb}$ MCL as recorded by four monitoring wells the in this area between 1986 and 1992: 4401 Park West, 4503 Park Rd, 4601 Park Rd, and 4742 Park Rd. This zone can be interpreted as the center of the Western Plume system. The result of the model calibration and locations of all 18 monitoring wells in the area are shown in Figure 3.10. The result from the calibration process including the mean error, the mean absolute error and the root mean square error between computed and observed data are $-0.51 \mathrm{ppb}, 13 \mathrm{ppb}$, and $26 \mathrm{ppb}$, respectively.

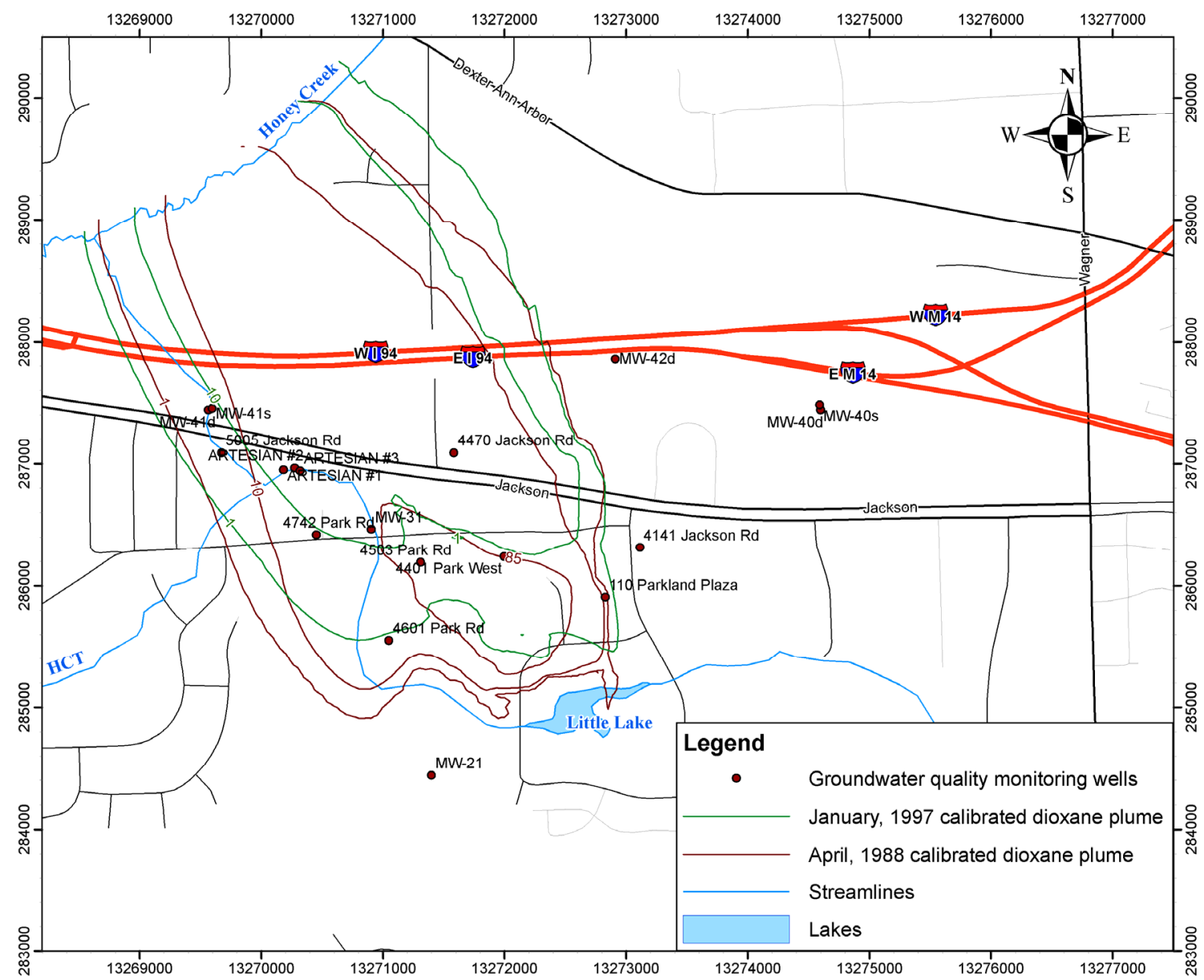

Figure 3.10 Calibrated plume delineation map in Lower Aquifer (isoconcentration contours are in ppb, Eastings and Northings are in feet). 


\section{Discussion}

The groundwater flow simulation and transport model of dioxane in the Western Plume system was developed on a basis of a four-layered conceptual model with respect to the previous work in this study area by Brode (2002) and subsequently Cypher and Lemke (2009), which was based on the M.S. thesis of Cypher (2008). In this thesis, additional transport processes were accounted for and some parameters were adjusted in order to cope with any possible circumstances which may influence on system behavior. The adaptation in this study compared to the previous models in the study area is outlined in Table 4.1

Table 4.1 Comparison of the published models to this study

\begin{tabular}{llll}
\hline Features & Brode (2002) & $\begin{array}{l}\text { Cypher and Lemke } \\
\text { (2009) }\end{array}$ & This work \\
\hline Flow model & MODFLOW: steady state & $\begin{array}{l}\text { MODFLOW: steady and } \\
\text { transient state }\end{array}$ & MODFLOW: steady state \\
No. of layers & 4 & 36 & 4 \\
K1 & 0.2 & 0.2 & 0.27 \\
K2 & 77 & 150 & 92 \\
K3 & 0.0006 & 0.2 & 0.005 \\
K4 & 200 & 200 & 160 \\
Recharge & Multiple zones (2-12 in/yr) & 7 in/yr & 9 multiple zones (4-12 \\
& & 33 & in/yr) \\
Observation wells & 8 & -0.1 & 31 \\
Mean residual & -0.12 & 0.98 & -0.01 \\
Mean absolute residual & 0.42 & 1.32 & 0.84 \\
Root mean squired & 2.33 & & 1.18 \\
& & MODPATH & MT3D \\
Transport model & MODPATH & 42 years (1965-2007) & 31 years (1966-1996) \\
Time frame & 25 years & Holding Pond, Third Sister Little Lake and Third \\
Source locations & SLD and Little Lake & Lake, and Little Lake & Sister Lake \\
advection & Forward particles tracking & Forward Particle tracking & Porosity of 0.3 \\
& at concentration of 10 & with porosity of 0.15 & \\
mispersion & - & - & Longitudinal dispersion: \\
retardation & - & - & $44.3 \mathrm{ft}$ \\
diffusion & - & & 1.6 \\
\hline
\end{tabular}




\section{Hydrogeologic Setting}

The top elevation structure of the Lower Confining Layer, particularly the linearhigh trend in the up-gradient area of the Western Plume south of Little Lake likely alters the direction of groundwater flow in the Upper Aquifer and isolates the Western Plume system from the other contaminated areas. Borehole log data for MW-51, MW-59sd and MW-66 support the interpretation of ridge structure in this confining unit, which is primarily silt and clay. The top elevations of the structure in this area are approximately 848 to 858 feet amsl with the maximum thickness of 119 feet. The interpretation of the ridge structure is also consistent with the hydrogeologic setting described in previous work (Brode, 2002; Cypher, 2008). In addition, the interpretation of no connection between the Western Plume system and Core area is supported by groundwater quality data for MW-51 well. This well, located adjacent to the Little Lake in down gradient of the Core area and the up gradient area of the Western Plume, has never detected the dioxane.

\section{Groundwater Flow Model}

The groundwater flow system was simulated under steady-state conditions. The result is consistent with the static water level in September 1995 with the mean absolute head residual less than one foot. However, the calibrated simulation did not strongly pronounce a component of groundwater flow northwesterly toward the Honey Creek, which is contrary to earlier conceptual models of the flow direction. The hydraulic gradient and component of groundwater flow were mainly influenced by the recharge, particularly the recharge of zone 5 which covers a majority of the Western Plume area. The hydraulic conductivity for the aquifers also has a great impact on the model output and groundwater flux between the aquifer system and source/sink. Adjustment of river conductances may improve the model result and influence the groundwater flow direction more northwest through the Western Plume system.

\section{Transport Model}

The transport simulation primarily considered the historical migration of dioxane in only the Upper Aquifer. According to the model result and literature review, a 
conclusion of Little Lake as a source location of dioxane in the Western Plume area is reasonable. Little Lake and adjacent rivers behave as losing stream and recharge water to the aquifer due to the difference between stream bed elevation and groundwater potentiometric surface. High precipitation during flooding period between 1967 and 1973 may cause an overflow from a wastewater treatment pond to the lower-elevation area nearby the PLS property (Brode, 2002). It is concievable that dioxane could have entered to the Little Lake via surface runoff. Surface water samples collected in early 1987 revealed the highest concentration of dioxane along the Honey Creek tributary at 293 ppb. The level of dioxane in the Little Lake was also measured and marked at only 20 ppb. Nevertheless, that is the first surface water quality data available in this area. There is no surface water quality measurement prior to 1987 to constrain the concentration of dioxane in the Little Lake.

In order to produce a precise plume extent and minimize the error between the observed data and simulated concentration, the retardation factor and ratio of horizontal transverse dispersivity to longitudinal dispersivity were manipulated during the calibration process. Adjusting these parameters directly impacts the plume attenuation rate and also produced more uncertainty to the system. The calibrated retardation factor and the ratio of horizontal transverse dispersivity to longitudinal dispersivity are 1.6 and 0.5 , respectively.

Although the Third Sister Lake seems not to be a source location of dioxane in the Western Plume area in the simulation, the connection between the Core area and Western Plume area should not be omitted. The potentiometric surface of water level in September 1995 does confirm the existence of this connection (Figure 2.4). Additional information from field observation and model refinement may reveal the other connection paths due to the hydrogeologic complexity of the area.

\section{Limitation and Uncertainty}

Due to spatial variability and limited site data for recharge and hydraulic properties, model input parameters always contain uncertainty. Many input parameters used in the simulations are not well constrained and solely based on calculation and assumption. River conductance, particularly in which of Sister Lakes, is a parameter that 
concern the result of groundwater flow in the area. Porosity is important when advective transport is considered. The transport model was calibrated by using the general value of porosity of 0.3 . Adjustment in this parameter will directly impact the average velocity and travel time of the contaminant in the system. Nevertheless, the simulations yielded reasonable results for groundwater flow and dioxane plume movement, albeit requiring significant calibration of important parameters (hydraulic conductivities, recharge rates, dispersivities, and the sorption coefficient).

The longitudinal dispersivity was adjusted during the calibration process. However, an increase in the initially assumed value resulted in the greater rate of plume attenuation, whereas decreasing the value resulted in numerical instabilities. Further grid refinement would be required to facilitate the lower dispersivity value. The calculated dispersivity of 44 feet is therefore used as a fixed parameter during the calibration. The ratio of horizontal transverse dispersivity to longitudinal dispersivity also impacted the model output. The higher ratio would extend the plume edge but decrease time in which dioxane would remain in the system.

Since the model input of this study primarily rely on publicly available data, the accuracy of the data is also necessary to be carefully examined. During the interpretation of hydrogeology process, ground surface elevations of two boreholes data provided by the state government seemed likely to be incorrect. After comparing with the DEM and ground elevations of the neighbor boreholes, the elevations were found to be shifted 100 feet.

\section{Future Work}

Development of conceptual models is common, especially for sites with significant geologic complexity. Comparison of alternative conceptual model performance may further the understanding of the system. In this study, the conceptual model is developed based on the limited available data such as borehole data, precipitation data, river conductance, and hydraulic conductivity. Although the head residuals produced from the simulation are quite low, with the mean absolute residuals less than one foot, uncertainty from hydrostratigraphic complexity still exists. Thus, 
further refinement on the conceptual model with additional information may be necessary.

Although steady-state simulations resulted in no evidence of hydraulic connection between the contamination in the Western Plume system and the Core area, transient simulations may be necessary in order to observe if there is a relationship between those areas after the pumping remediation. In addition, an annual measurement of surface water bodies, particularly Honey Creek and its tributaries should be performed in order to provide more precise data for surface water and groundwater interaction.

The simulation of dioxane transport in this study relies on many simplified hydrogeologic assumptions. The interpretation of stratigraphy from borehole data was tentatively based on the four-layered conceptual model. Some units may not be necessary to be correlated. There is still a potential for improvement in hydrostratigraphic interpretation and conceptual model modification for future work. It is likely that a more complex conceptual model with well-defined constraints on site characteristics would provide better model results. Additional field data and alternative models based on this model assessment are therefore recommended in the future.

An alternative conceptual model can still be developed based on the assumption of a 4-layer model but the following factors should be accounted in the new simulation:

Stratigraphy: In this study, the boundaries of the subsurface layer are created by the interpolation of unit contacts in borehole data which resulted in uncertainty. Modification of the hydrostratigraphy in the study area may help in better describing the subsurface behavior and reveal more subsurface structures which characterize the aquifer system.

Streamflow: It is suggested that gaining and losing streams, including surface flow, should be accounted for in alternative conceptual models. Additional measured stream flow and conductance data of the hydrographic features, particularly the Second Sister Lake, should be acquired and considered along with the groundwater and surface water interaction.

Anisotropy of the conductivity: Since this study assumes that each subsurface layer is homogeneous, the anisotropy of the conductivity should be considered in the 
alternative conceptual model. Anisotropy of hydraulic conductivity could be accounted in order to contribute groundwater flow direction more northwesterly through the Western Plume area and consequently enhance a delineation of the dioxane plume. However, the anisotropy ratio should be determined and carefully applied to reduce uncertainty. 


\section{Conclusions}

The objective of this study is to demonstrate the utility of publicly data in groundwater modeling and to delineate the historical migration of dioxane in the Western Plume system. Simulation of groundwater flow and dioxane transport was accomplished by using publicly available data and models. Although, the state government data is quite sparse and limited in terms of spatial and temporal resolution, it is still considerably adequate for a regional-scale model. The modeling approach used herein relied on a fourlayer conceptual model with respect to previous representative models in this area. Data analysis and model results indicate the heterogeneity and complexity of the aquifer system. Calibrated steady-state simulations produced a component of groundwater flow northwest through the Western Plume toward the Honey Creek.

The historical plume migration was adequately simulated until the concentration level was naturally below the generic residential cleanup criterion of $85 \mathrm{ppb}$. The simulated plume geometries were, however, not well constrained due to insufficient groundwater quality data and scattered monitoring well network. Little Lake is found to be the most possible source location that contributed the dioxane to the Western Plume system. The simulation successfully demonstrated the development and migration of the contaminant in this area

In conclusion, publically available data can be used with publically available models to adequately simulate field conditions in a complex glacial aquifer system contaminated with 1,4-dioxane. The significant advantage of this approach includes an appropriate result with fewer field data requiring, less time-consuming, and more cost effective than additional site investigations for model-specific input. 


\section{References}

Abe, A. (1999). Distribution of 1,4-dioxane in relation to possible sources in the water environment. Sci. Total Environ., 227, 41-47.

Adams, C. D., Scanlan, P.A., and Secrist, N. D. (1994). Oxidation and Enhancement of 1,4-Dioxane Using Hydrogen Peroxide and Ozone. Environmental Science and Technology, 28, 1812-1818.

Agency for Toxic Substances and Disease Registry (ATSDR). (2007). Toxicological Profile for 1,4-Dioxane (Draft for Public Comment). Atlanta, GA: U.S. Department of Health and Human Services, Public Health Services.

Alpha Geosciences. (1993). Report on the Western Plume sytem aquifer evaluation, Report prepared for Gelman Sciences Inc. Kalamazoo, MI: Alpha Geosciences, Inc.

Anderson, M. P., and Woessner, W. W. (1992). Applied Groundwater Modeling: Simulation of Flow and Advective Transport. San Diego: Academic Press.

Baginska, B., Milne-Home, W. and Cornish, P. (2003). Modelling nutrient transport in Currency Creek, NSW with AnnAGNPS and PEST. Environ. Modell. Softw. , 18, 801-808.

Bahremand, A., and De Smedt, F. (2008). Distributed Hydrological Modeling and Sensitivity Analysis in Torysa Watershed, Slovakia. Water Resour Manage , 22, 393-408.

Ball, R. C. (1947). A tagging experiment on the fish population of Third Sister Lake, Michigan. Transactions of the American Fisheries Society, 74, 360-369.

Bridgeman, T. B., Wallace, C. D., Carter, G. S., Carvajal, R., Schiesari, L. C., Aslam, S., Cloyd, E., Elder, E., Field, A., Schulz, K. L., Yurista, P. M., and Kling, G. W. (2000). A Limnological Survey of Third Sister Lake, Michigan with Historical Comparisons. Journal of Lake and Reservoir Management , 16 (4), 253-267.

Brode, J. W. (2002). The role of groundwater and surface water interaction in the development of a 1,4-dioxane plume in Scio Township, Washtenaw County, Michigan [M.S. thesis]. Western Michigan University.

Cypher, J. A. (2008). Hydrogeologic modeling of a 1,4-dioxane plume in a glacial aquifer system; Washtenaw County, Michigan [M.S thesis]: Wayne State University, Michigan. 
Cypher, J. A., and Lemke, L. D. (2009). Multiple Working Transport Hypotheses in a Heterogeneous Glacial Aquifer System. Ground Water Monitoring and Remediation, 29 (3), 105-119.

Doherty, J. (2004). PEST-Model Independent Parameter Estimation User Manual (5th ed.). Brisbane, Australia: Watermark Numerical Computing.

Ebraheem, A. M., Riad S., Wycisk P., and Sefelnasr A. M. (2004). A local-scale groundwater flow model for groundwater resources management in Dakhla Oasis, SW Egypt. Hydrogeology Journal (12), 714-722.

Eichenlaub, V. L., Harman, J. R., Nerberger, F. V., and Stolle, H. J. (1990). The Climatic Atlas of Michigan. Notre Dame, IN: The University of Notre Dame Press.

Fetter, C. W. (2001). Applied Hydrogeology (4th ed.). Upper Saddle River, New Jersey: Prentice-Hall, Inc.

Fetter, C. W. (1999). Contaminant Hydrogeology (2nd ed.). Upper Saddle River, NJ: Prentice Hall, Inc.

Fincher, E. L., and Payne, W. J. (1962). Bacterial Utilization of Ether Glycols. Appl Microbiol. , 10 (6), 542-547.

Fleck, W. B. (1980). Geology and hydrology for environmental planning in Washtenaw County, Michigan: U.S. Geological Survey Open-File Report.

Freeze, R. A., and Cherry, J. A. (1979). Groundwater. Englewood Cliffs, NJ: Prentice Hall.

Goldsworthy, T. I., Monticello, T. M., Morgan, K. T., Bermudez, E., Wilson, D. M., Jaeckh, R., Butterworth, B. E. (1991). Examination of Potentials Mechnicisms of Carcinogenicity of 1,4-Dioxane in Rats Nasal Epithelial Cells and Hepatocytes. Archives of Toxicology, 65 (1), 1-9.

Grady, C. P. L., Sock, S. M., and Cowan, R. M. (1997). Biotreatability kinetics-a critical component in the scale-up of wastewater treatment systems. In G. S. Sayler, J. Sanseverino, \& K. L. Davis (Eds.), Biotechnology in the sustainable environment. Plenum, New York.

Hammer, B. K., and Stoermer, E. F. (1997). Diatom-based interpretation of sediment banding in an urbanized lake. Journal of Paleolimnology, 17, 437-449. 
Harbaugh, A. W., Banta, E. R., Hill, M. C., and McDonald, M. G. (2000). MODFLOW2000, The U.S. Geological Survey Modular Ground-Water Model--User Guide to Modularization Concepts and the Ground-Water Flow Process: U.S. Geological Survey Open-File Report 00-92.

Healy, D. F. (2005). Ground-Water/Surface-Water relations along Honey Creek, Washtenaw County, Michigan, 2003: U.S. Geological Survey Open File Report 2004-1387,.

Hill, M. C., Tiedeman, C. R. (2007). Effective Groundwater Model Calibration: With Analysis of Data, Sensitivities, Predictions, and Uncertainty. Hoboken, New Jersey: John Wiley \& Sons, Inc.

Howard, P. H. (1991). Handbook of Environmental Degradation Rates. Chelsea, MI: Lewis Publishers, Inc.

Lesage, S., Jackson, R. E., Priddle, M. W., and Riemann, P. G. (1990). Occurrence and fate of organic solvent residues in anoxic groundwater at the Gloucester landfill, Canada. " Environ. Sci. Technol. , 24, 559-566.

McDonald, M. G., and Harbaugh, A. W. (1988). A modular three-dimensional finitedifference ground-water flow model: U.S. Geological Survey Techniques of Water-Resources Investigations, book 6, chap. A1.

MDEQ. (2004). Information bulletin: Gelman Sciences, Inc. site, Scio Township, Washtenaw County, Michigan, March. Lansing, MI: Michigan Department of Environmental Quality.

MDEQ. (2006). State of Michigan Public Act 148: Groundwater Inventory and Map (GWIM) Project, Technical Report.

Michigan Center for Geographic Information. (n.d.). Geographic Data Library. Retrieved June 24, 2009, from http://www.mcgi.state.mi.us/mgdl/

Mohr T. K., Stickney J. A., and DiGuiseppi W. H. (2010). Environmental Investigation and Remediation: 1,4-Dioxane and Other Solvent Stabilizers. Boca Raton, FL: CRC Press.

Mohr, T. K. (2001). Solvent Stabilizers White Paper. San Jose, CA: Santa Clara Valley Water District.

National Oceanic and Atmospheric Administration (NOAA). (2009). Online Climate Data Directory. Retrieved June 24, 2009, from http://www.ncdc.noaa.gov/oa/climate/climatedata.html 
PLS. (2004). Final feasibility study and proposed interim response plan for the Unit E plume.

PLS. (2006). Interim response work plan Western System.

Pollack, D. W. (1994). User's guide for MODPATH/MODPATH-PLOT, version 3: A particle tracking post-processing package for MODFLOW, the U.S. Geological Survey finite-difference ground-water flow model: U.S. Geological Survey OpenFile Report 94-464.

Potzger, G. E., and Wilson, I. T. (1941). Post-pleistocene forest migration as indicated by sediments from three deep inland lakes. The American Midland Naturalist , 25, $270-281$.

Priddle, M. W., and Jackson, R. E. (1991). Laboratory column measurement of VOC retardation factors and comparison with field values. Ground Water , 28 (2), 260266.

Schulze-Makuch, D. (2005). Longitudinal dispersivity data and implications for scaling behavior. Ground Water , 43 (3 ), 443-456.

Skadsen, J. M., Rice, B. L., and Meyering, D. J. (2004). The occurrence and fate of pharmaceuticals, personal care products and endocrine disrupting compounds in a municipal water use cycle: a case study in the city of Ann Arbor. City of Ann Arbor: Water Utilities and Fleis \& VandenBrink Engineering, Inc.

Spitz, K., and Moreno, J. (1996). A Practical Guide to Groundwater and Solute Transport Modeling. New York, NY: John Wiley \& Sons, Inc.

Steffan, R. J. (2006, December 6). Biodegradation of Ether-Containing Pollutants. Retrieved February 24, 2010, from Federal Remediation Tehnologies Roundtable Meeting: www.frtr.gov/pdf/meetings/dec06/steffan120606.pdf

Tang, Y., Reed, P., Wagener, T., and van Werkhoven, K. (2007). Comparing sensitivity analysis methods to advance lumped watershed model identification and evaluation. Hydrol. Earth Syst. Sci. , 11, 793-817.

Twenter, F. R., Khutilla, R. L., and Nowlin, J. O. (1976). Water resources of Washtenaw County, Michigan: Washtenaw County Planning Commission.

U.S. Environmental Protection Agency (USEPA). (2006). Treatment Technologies for 1,4-Dioxane: Fundamentals and Field Applications. Washington, DC. 
USGS. (n.d.). USGS Surface Water for Michigan: Stream flow Measurements. Retrieved December 27, 2009, from National Water Information System: Web Interface: http://waterdata.usgs.gov/mi/nwis/measurements?county_cd=26161

Zheng, C., and Wang, P. P. (1999). MT3DMS: A Modular Three-Dimensional Multispecies Transport Model for Simulation of Advection, Dispersion and Chemical Reactions of Contaminants in Groundwater Systems; Documentation and User's Guide. U.S. Army Engineer Research and Development Center. 